\begin{abstract}
UNIVERSIDADE DE SÃO PAULO
FACULDADE DE FILOSOFIA, LETRAS E CIÊNCIAS HUMANAS DEPARTAMENTO DE LETRAS CLÁSSICAS E VERNÁCULAS ÁREA DE ESTUDOS COMPARADOS DE LITERATURAS DE LIINGUA PORTUGUESA
\end{abstract}

CRISTIANE SANTANA SILVA

A palavra (re)inventada: pelos caminhos da harmonia e da violência

(Uma leitura de estórias de João Guimarães Rosa e José Luandino Vieira) 


\begin{abstract}
UNIVERSIDADE DE SÃO PAULO
FACULDADE DE FILOSOFIA, LETRAS E CIÊNCIAS HUMANAS DEPARTAMENTO DE LETRAS CLÁSSICAS E VERNÁCULAS ÁREA DE ESTUDOS COMPARADOS DE LITERATURAS DE LIINGUA PORTUGUESA
\end{abstract}

\title{
A palavra (re)inventada: pelos caminhos da harmonia e da violência \\ (Uma leitura de estórias de João Guimarães Rosa e José Luandino Vieira)
}

Dissertação apresentada ao Programa de Pós-Graduação em Estudos Comparados de Literaturas de Língua Portuguesa, do Departamento de Letras Clássicas e Vernáculas da Faculdade de Filosofia, Letras e Ciências Humanas da Universidade de São Paulo como exigência à obtenção do título de Mestre.

Orientação: Prof. ${ }^{a}$. Dra. Tania Celestino de Macêdo 
SILVA, Cristiane Santana. A palavra (re)inventada: pelos caminhos da harmonia e da violência. Uma leitura de estórias de João Guimarães Rosa e José Luandino Vieira. Dissertação apresentada ao Programa de Pós-Graduação em Estudos Comparados de Literaturas de Língua Portuguesa do Departamento de Letras Clássicas e Vernáculas da Faculdade de Filosofia Letras e Ciências Humanas da Universidade de São Paulo.

Aprovada em:

Banca Examinadora:

Prof. Dr.: Instituição:

Julgamento: Assinatura:

Prof. Dr: Instituição:

Julgamento: Assinatura:

Prof. Dr:: Instituição:

Julgamento: Assinatura: 
Dedico este trabalho a Antônia Maria da Conceição (in memoriam), que sendo uma das melhores narradoras que conheci, me despertou o gosto por estórias.

E a Maria das Neves Santana, por tudo! 


\section{Agradecimentos}

À professora Tania Macêdo por acreditar que eu poderia desenvolver este trabalho, pela orientação precisa, pela amizade, pela paciência e confiança, mesmo diante de todas as minhas dificuldades.

Aos professores Mário César Lugarinho e Salete de Almeida Cara pela leitura cuidadosa e pelas preciosas contribuições durante o exame de qualificação e à professora Leila Maria Gonçalves Leite Hernandez pela sinalização de caminhos ainda não percorridos.

A minha mãe, pelo amor incondicional e pelo irrestrito apoio durante toda a minha trajetória na universidade, sempre acreditando, mesmo quando não compreendendo, em todas as minhas escolhas.

A minha família, os amados: Antônio, sempre disposto a ajudar; Alexandre, Rafael e Rodrigo, irmãos e companheiros no cotidiano; e ao Mateus, o mais novo, lindo e vivaz.

Aos malungos e malungas, pelo companheirismo ímpar, pelos ideais compartilhados e pela experiência no Nupe (Núcleo Negro da Unesp para Pesquisa e Extensão), que, espero, se estenderá por toda a vida: Ana Cristina, André, Camila, Carla, Joilson, Marilene, José, Geraldo, Thiago, Cibele, Edileuza, Oluemi e Alex (que não esteve em Assis, mas igualmente malungo), e aos professores Sérgio Augusto Queiróz Norte e Carmen Silvia Carvalho.

Às amigas que se fizeram durante a graduação em Assis (e também antes), com as quais dividi e continuarei dividindo importantes momentos da minha vida, e que tornam o "estar aqui" muito mais significativo: Daniela Caetano, Kelly Moraes, Andreia Marques, Aline Ortolani e Marília Rosa. E também aos amigos, que 
igualmente constituem esta trajetória: Ronaldo e Ivan (irmão por escolha) .

A Adriana Moreira, parceira das pequenas e grandes revoluções, de sonhos e projetos realizados e por vir; com quem venho construindo meu colar de cores amigadas, cada dia mais bonito.

A Uvanderson Silva, pela desejada e essencial presença, construída em afeto, sobretudo, mas também em ideias, oportunos e felizes encontros, sons, silêncios e contínuo aprendizado.

Aos amigos que ganhei na trajetória uspiana, com quem aprendi ser possível outras presenças e olhares dentro da universidade: contestatórios, coloridos, musicais e perspicazes.

À FAPESP, Fundação de Amparo à Pesquisa do Estado de São Paulo, pela bolsa que possibilitou o desenvolvimento deste trabalho.

A Deus. 
A gente perdemos sempre, mas nunca que desistimos... (Memória Narrativa ao Sol do Kinaxixi José Luandino Vieira)

A vida às vezes podia raiar numa verdade extraordinária [...] entre a desilusão e 0 contentamento, na balança infidelíssima, quase nada medeia. (As margens da Alegria - João Guimarães Rosa) 


\section{RESUMO}

O trabalho ora apresentado tem como proposta a leitura, sob o pondo de vista comparatista das estórias presentes em Primeiras estórias, de João Guimarães Rosa, publicado pela primeira vez em 1962, e No antigamente, na vida, de José Luandino Vieira, de 1974. Parte-se do mapeamento do percurso da (re)invenção inscrita no tempo da infância, para posteriormente, sob o recorte da caracterização das personagens infantis, verificar a ficcionalização da violência através destas personagens, marcadas por dois movimentos distintos: através da compreensão da presença ou do passado colonial e das identificações nacionais, do intento harmonizador, em Guimarães Rosa, e da evidenciação da violência, temática e estruturalmente, em Luandino Viera.

Palavras-chave: recriação; identidades nacionais; personagem infantil; harmonia; violência. 


\begin{abstract}
The presented dissertation has as purpose a literary reading through a comparative point of view between the shorts stories from the books: Primeiras Estórias, written by João Guimarães Rosa, published for the first time in 1962 and No antigamente, na vida, by José Luandino Vieira, published in 1974. It is started with a map of the pathway of (re)invention, set in childhood time. After that, it is checked the fiction process of the violence made up through the infantile characters marked by for two distinguished movements: through the comprehension of the presence of the colonial past and national identification, through the harmonic intent present in Guimarães Rosa writings and also through the disclosure of violence, that is thematic and structural José Luandino Vieira short stories.
\end{abstract}

Keywords: recreation; national identities; infantile characters; harmony; violence . 


\section{SUMÁRIO}

\section{Apresentação}

Situando o percurso de leitura.

Capítulo 1: A palavra e a (re)invenção: estabelecendo contatos.

1.1. O caráter (re)inventivo: diálogos transculturais.....................................16

1.2. As crianças, a palavra: caminhos da estruturação narrativa............................26

1.3. Guimarães Rosa: a missão de harmonizar forças contrárias.........................31

1.4. Luandino Vieira: alternativas do escritor colonizado...................................35

Capítulo 2: A palavra e as identidades nacionais: estabelecendo o percurso das diferenciações.

2.1. Imagens das identidades nacionais na literatura.

2.2. O discurso colonial português: entre a harmonização e a impossibilidade de assimilação.

2.3. Dos modos de pensar a infância .55

2.4. Dos modos de pensar/lidar a violência. 60

\section{Capítulo 3: A palavra singular: do triunfo da alegria à emergência da violência}

3.1. Da "Partida do Audaz Navegante" às aventuras do 'aldaz' navegante: suplantando as faltas no devir da fantasia.........................................................64

3.2. Quando não se entende coisa alguma é que o sentido dado está....................68

3.3. Para a grande cidade: harmonia como estrutura arquitetônica........................70

3.4. "Pirlimpsiquice": o mundo que se acaba na queda e (re)volta, são e glorioso.....80

3.5. Para Tetembuatubia: os de cá, os de lá..................................................... 85

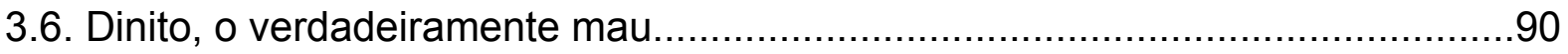

3.7. "Memória Narrativa ao Sol do Kinaxixi" - a beleza suspendida em três tempos de violência............................................................................................92



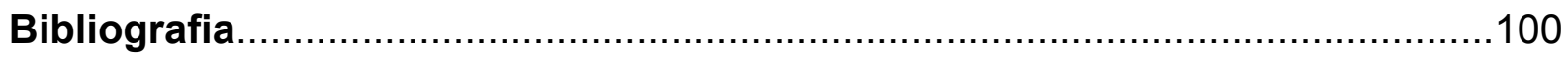




\section{Apresentação}

\section{Situando o percurso de leitura}

As obras ficcionais de João Guimarães Rosa (1908-1967) e de José Luandino Vieira (1935), configuram escritas de incontestável relevância no sistema literário de seus países, nomeadamente, Brasil e Angola. Desta forma, muitos são os estudos que se debruçaram sobre a produção destes escritores, que por uma forte confluência estilística, e por vezes, temática, permitiram fecundas aproximações entre suas escritas.

Ao eleger estes autores para uma pesquisa nos preocupava que tipo de contribuição, embora limitada, poderíamos trazer a uma discussão acadêmica que já apresenta importantes trabalhos comparativos entre os escritores. E para responder a tal preocupação, elegemos as narrativas ${ }^{1}$ "Partida do Audaz Navegante", "As margens da alegria", "Pirlimpsiquice", "A menina de lá" e "Os cimos" presentes em Primeiras Estórias, de Guimarães Rosa, publicado pela primeira vez em 1962, e No Antigamente, na vida, livro de Luandino Vieira de 1974, embora, segundo o autor, escrito entre os anos de 1967 e $1969^{2}$.

A escolha de tais textos fez-se num primeiro momento por observarmos que dentre as pesquisas acadêmicas que comparavam a produção de Rosa e Luandino não figuravam estudos que se detivessem em uma análise comparativa das

1 As narrativas foram escolhidas levando em consideração o protagonismo das personagens infantis, o que não ocorre em todo o volume.

2 Os intervalos de tempo entre a escrita e a publicação das obras de Luandino Vieira decorrem, principalmente, do fato de que o autor produziu maior parte de sua fiç̧ão nos anos em que se encontrava preso no campo de concentração do Tarrafal, Cabo Verde, sendo a maioria das obras publicadas depois de sua saída em 1972. 
narrativas e, posteriormente, por se inserirem em um universo ficcional que nos propiciariam uma leitura que escapasse do escopo crítico de fonte e influência.

As narrativas de Rosa e Vieira tornam-se próximas no sentido de uma convergência de procedimentos estéticos e temáticos. No entanto, o esforço deste trabalho será o de buscar imprimir uma singularidade às obras de um e outro autor, e para tal, a leitura se pautará, sobretudo, em identificar no trabalho realizado pelos escritores as diferentes atualizações dos procedimentos supracitados, levantando na linguagem as características de um projeto estético (sublinhando questões ideológicas, sociológicas, políticas e históricas), o que acabará por diferenciá-los, principalmente, no que tange ao contexto de criação das obras.

Como não é possível ignorar a confluência entre a escrita de Rosa e Luandino (constatação que, a princípio, permitiu o alinhamento destes textos para esta proposta de estudo), o encaminhamento deste trabalho tomará, inevitavelmente, dois horizontes de leitura: o primeiro deles, como ponto de partida, procurará frisar o que é comum aos textos, tanto na formalização estética, como em experiências sócio-históricas comuns e o segundo, na análise das personagens infantis considerando as maneiras pelos quais os autores apreendem e ficcionalizam a violência, diferenciar as proposições estéticas e intelectuais dos autores.

Neste sentido, dedicamos o primeiro capítulo a estabelecer um diálogo entre as teorias latino-americanas sobre as recriações, ancoradas, principalmente, no conceito de transculturação proposto por Ángel Rama, que em linhas gerais, está ocupado da autonomia das letras latino-americanas frete às imposições coloniais, marcando, sobremaneira, o protagonismo dos agentes culturais destes países na manipulação de diferentes matérias na composição textual: "Se esta [a criação] é 
vivente, cumprirá essa seletividade sobre si mesma e sobre o aporte exterior e, obrigatoriamente, efetuará invenções com 'ars combinatorio' adequado à autonomia do próprio sistema cultural“33. (RAMA, 1987, p.38)

Assim, durante esta aproximação a tentativa será a de compreender a ressemantização empreendida pelos autores como este movimento que irá congregar o externo e o interno, e daí situarmos a linguagem dos escritores sob o signo da "palavra (re)inventada", ou seja, como se o código tomado a princípio, a língua portuguesa, tornasse-se outro, a partir de tensões, revitalizações, questionamentos e subversões dos sentidos, assumindo um papel emancipador, ou como bem o capta Silviano Santiago a despeito do lugar das letras latinoamericanas no cânone ocidental:

\begin{abstract}
A América Latina institui seu lugar no mapa da civilização ocidental graças ao movimento de desvio da norma, ativo e destruidor, que transfigura os elementos feitos e imutáveis que os europeus exportavam para o Novo Mundo (SANTIAGO, 2000, p. 16)
\end{abstract}

No exame da vida cultural realizado por Silviano Santiago não está presente somente a perspectiva do colonizado que deseja emancipar-se, e do mesmo modo, não só a perspectiva do colonizador que pela força deseja "civilizar", mas a natureza do encontro, das forças que concorrem, excluem-se e somam-se na formação do que chamará de "entre-lugar", no qual por fim, se instalará a cultura dos povos que intentam desvencilhar-se de jugo colonial.

Partindo daí, julgamos pertinente para dar continuidade a este trabalho, refletir sobre estas linhas de força e assim, o segundo capítulo procura tanto pensar

3 No original: Si esta es viviente, cumplirá esa selectividad, sobre si misma y sobre el aporte exterior y, obligadamente, efectuará invenciones com 'ars combinatorio' adecuado a la autonomía del propio sistema cultural" 
sobre o contexto de formação das identidades que desejam desligar-se do jugo colonial, bem como compreender como se deu o discurso colonial, no caso, o português, e suas continuidades, descontinuidades e reavaliações feitas nas narrativas.

Conjugando a reflexão sobre o discurso colonial à violência, pareceu-nos oportuno, considerar em nosso texto as contribuições de Frantz Fanon e Albert Memmi. Ambos pensadores, ao tratar a colonização (e os processos de descolonização) numa análise interna, isto é, "a partir" e não "sobre" o continente africano, tratam a violência como reguladora da lógica colonial, e avançam no sentido de compreender a violência que surge como resposta do colonizado (durante as lutas de libertação nacional) fazendo parte de uma prática que visa libertar o colonizado de uma possível alienação a que o tenha submetido o colonialismo.

Como a leitura aqui, concentrou-se na observação das personagens infantis, dedicamos, também, parte do segundo capítulo para pontuar como as imagens da criança e da infância entram em tal jogo, para por fim, conjugar tal imaginário com a representação nas obras cotejadas e, deste modo, poder observar localizar os movimentos de harmonização e evidenciação da violência que norteia a leitura.

Isto posto, procuramos, então, determinar como a violência surge no contexto africano, na galeria de personagens que, como nos diz Ana Paula Tavares, "deslizam e crescem no silêncio, mestres na arte de praticar o bem e exercer o mal" ${ }^{4} E$ por outro lado, estão as crianças da ficção rosiana, representadas num quadro "harmônico" ou em que, no limite, as tensões acabam por dissolver-se.

No último capítulo concentramo-nos mais nas estórias, procurando fazer uma

4 A presente citação encontra-se na orelha da edição de 2005 de No antigamente, na vida. 
leitura mais detalhada das personagens, cuja orientação e abordagem se aproximam daquela proposta por Anatol Rosenfeld em "Literatura e Personagem":

[...] o grande da obra de arte literária (ficcional) é o lugar em que nos defrontamos com seres humanos de contornos definidos $e$ definitivos, em ampla medida transparentes, vivendo situações exemplares de um modo exemplar (exemplar também no sentido negativo). Como seres humanos encontram-se integrados num denso tecido de valores de ordem cognoscitiva, religiosa, moral, político-social e tomam determinadas atitudes em faces desses valores [...] (ROSENFELD, 2004, p. 45)

Desta forma, observaremos as personagens em consonância com suas atitudes e gestos, procurando articular tal observação aos problemas e perguntas suscitadas nos capítulos anteriores, encerrando o percurso da leitura com intento de demonstrar que nas obras surgem profícuas possibilidades de particularizar procedimentos estéticos bastante confluentes. 


\section{1 - A palavra e a (re)invenção: estabelecendo as pontes iniciais}

Pelo que delimitamos nos pressupostos deste trabalho, o percurso de leitura se fez de aproximações e afastamentos, e a questão da recriação (de linguagem, de espaços e de temporalidades), paradoxalmente, é o ponto de maior confluência entre os textos, ao mesmo tempo, em que a partir dele é que pudemos singularizar a escrita de Guimarães Rosa e Luandino Vieira.

Deste modo, para que se efetive o percurso proposto, iniciaremos o capítulo por tais aproximações, para em seguida, mapear quais seriam as soluções estéticas encontradas pelos escritores.

\subsection{O caráter (re)inventivo: diálogos transculturais}

O ponto comum a que nos referimos anteriormente, ou seja, a questão da recriação, o qual, aliás, permitiu-nos trilhar a leitura a partir do viés da "palavra reinventada", será analisado, sobretudo, com base na perspectiva de transculturação narrativa proposta pelo crítico uruguaio Ángel Rama, proposição teórica que nos pareceu pertinente por situar a construção narrativa a partir dos eixos: independência, originalidade e representatividade, que mesmo em contextos diversos como são os de Guimarães Rosa e Luandino Vieira, permitem a aproximação dos textos num sentido de que as literaturas produzidas em países que passaram pela experiência da colonização expressarão, de variadas formas, um desejo de autonomia e de especificidade frente às imposições coloniais, no caso 
angolano, ou dos impasses do projeto de modernização, problematizado pelo passado colonial, no brasileiro.

Rama irá propor o conceito a partir do que já fora trabalhado por Fernando Ortíz que se pautando nas reflexões sobre aculturação desenvolvidas, principalmente, com a colonização europeia e os processos de descolonização do século $X X$, instaura uma insuficiência do termo para o pensamento dos contatos culturais forjados nestes contextos, pois:

Entendemos que el vocablo transculturación expresa mejor las
diferentes fases del proceso transitivo de una cultura a otra, porque
éste no consiste solamente en adquirir una cultura, que es lo que en
rigor indica la voz anglo-americana "aculturación", sino que el
proceso implica también necesariamente la pérdida o desarraigo de
una cultura precedente, lo que pudiera decirse una parcial
desculturación, y, además, significa la consiguiente creación de
nuevos fenómenos culturales que pudieron denominarse
neoculturación. (ORTIZ apud RAMA, 1987, pp. 32-33)

$\mathrm{Na}$ contramão de leituras que veriam neste conceito de transculturação o movimento de passagem de uma cultura a outra, Rama o entende não apenas como um simples conglomerado de normas, comportamentos, crenças e objetos culturais, mas dotada de uma força criadora que "atua com desenvoltura tanto sobre a herança particular [...] como sobre os aportes vindos de fora". ${ }^{5}$ (RAMA, 1987, P. 34)

No entanto, o conceito de Ortíz traria alguns problemas para se pensar as narrativas latino-americanas, pois faltariam elementos que pudessem atender aos critérios de invenção e seletividade, para os quais, avançando nas reflexões de seu predecessor, Rama propõe a ideia de "plasticidade cultural", compreendendo que

5 No original: "actua com desenvoltura tanto sobre su herencia particular [...], como sobre las aportaciones provenientes de fuera". 
desta forma, estariam garantidas a energia e a criatividade de uma comunidade cultural, implicando, destarte, movimento, dinamismo e protagonismo dos agentes envolvidos no processo de negociação dos bens culturais constituintes das identidades encenadas no corpo de tais narrativas:

Si esta es viviente, cumplirá esa selectividad sobre si misma y sobre el aporte exterior y, obligadamente, efectuará invenciones con 'ars combinatorio' adecuado a la autonomía del propio sistema cultural" (RAMA, 1987, p. 38).

Assim, o autor retoma uma vez mais a tendência independentista das letras latino-americanas reforçando que neste processo de escolha e busca de autonomia, mesmo as fontes vindas das "metrópoles" serão aquelas que de certa maneira recusam o sistema europeu, ou seja, há em suas considerações um esforço por demonstrar o lugar de sujeitos atuantes e criadores dos transculturadores, resumindo suas ações em quatro operações que para ele seriam concomitantes e se resolveriam dentro de uma reestruturação geral do sistema cultural: perdas, seleções, redescobrimentos e incorporações, as quais, em conjunto, representariam a função criadora que cumpre o processo de transculturação.

Para além de caracterizar as linhas de força das narrativas transculturadoras, o crítico ainda faz uma divisão de suas instâncias operacionais, nomeadamente, a língua, a estruturação literária e a cosmovisão, concentrando a análise nas soluções artísticas encontradas pelos escritores.

No que tange à língua, o autor ressalta que tanto no período de modernização do final do século XIX, como no entre guerras do século XX, o idioma aparece como reduto defensivo e como prova de independência e, sendo assim, a preocupação com o idioma não poderia deixar de figurar as narrativas dos transculturadores. $\mathrm{O}$ 
crítico destaca que as narrativas destes últimos, em contraponto com as dos regionalistas $^{6}$, não somente incorporavam registros fonéticos ou léxicos regionais, mas encurtariam as distâncias entre as normas culta e popular, ao incorporarem o falar regional ao contexto artístico da obra; como exemplo profícuo desta operação Rama situa a obra de Guimarães Rosa, afirmando que o escritor consegue elevar aportes dialetais a unidades de uma estruturação, que por seu turno, seria regida pelos princípios da composição artística:

[...] en este nivel, la contribución original de los transculturadores, consiste en la unificación lingüística del texto literario, respondiendo a los principios de unificación artística pero utilizando en sustitución de una lengua literaria compuesta y aprendida, la suya propia. ${ }^{7}$ (RAMA, 1974, p. 20)

Todavia, cumpre ressaltar que o autor analisa a operacionalização da língua e o esforço de construir uma totalidade dos falares no romance Grande Sertão: Veredas, no qual os possíveis distanciamentos entre o culto e o regional são minimizadas na figura do narrador Riobaldo.

Tal procedimento não pode ser lido sem ressalvas nos contos de Primeiras Estórias, sob o risco de incorrermos numa filiação irrestrita aos conceitos do crítico, o que não é a intenção do trabalho que, ao invés disso, busca perceber os encontros

6 Embora não tenhamos tratado este ponto no trabalho, o conflito do regionalismo, movimento que surge no contexto das independências dos países latino-americanos, residiria, principalmente, no trato com a modernização: retroceder, entrando em agonia ou renunciar aos valores regionais, decretando sua própria morte.

7 Todas as referências feitas ao texto de Ángel Rama realizadas neste texto estão presente no livro Transculturación Narrativa en América Latina, com exceção desta, presente num ensaio anterior ao livro que o autor incluirá, mais tarde, neste último com modificações e ampliações, formando os capítulos 1 e 2 do primeiro, cuja $1^{\text {a }}$ edição data de 1982. RAMA, Ángel. Los procesos de transculturación en la Narrativa Latinoamericana. In: Revista de Literatura Hispanoamericana, n. 5, abril/1974. 
entre as proposições de Rama e a estruturação das obras ficcionais estudadas.

Dito isto, notamos que no conjunto das estórias de Rosa, mesmo seguindo a tônica de uma estruturação que visava eliminar distinções entre narrador culto e personagens locais, existem momentos em que se evidenciam algumas tensões, ou seja, é possível visualizar alguns olhares que parecem vir "de fora" dos fatos narrados, opondo perspectivas e demonstrando algumas fissuras de tal empresa. $\mathrm{O}$ que ocorre, por exemplo, em contos como "Pirlimpsiquice", que a partir de considerações do próprio narrador, parecem revelar as ambiguidades deste processo, metaforizadas pela queda final do conto, a qual rompe o infinito ciclo fabulativo, e revela ainda um certo distanciamento entre realidade e recriação simbólica, dando uma simulada consciência das "perdas" desta recriação.

Procurando, desde já, estabelecer paralelos desta crítica da literatura latinoamericana com o contexto das literaturas produzidas nos países de língua oficial portuguesa, destacadamente Angola, nos parece relevante observar os estudos de Laura Cavalcante Padilha, sobretudo em seu livro Entre voz e letra: o lugar da ancestralidade na ficção angolana do século $X X$, que nos oferece um painel de reflexões que englobam num amplo panorama, aspectos como a reinvenção da tradição na modernidade e o trabalho estético angolano com a linguagem literária, e dentro das quais, - analisando a maneira como os autores (re)construíam em seus textos a palavra que era deixada de fora do centro, espaço em que a cultura dominante ditaria suas leis - , define tal movimento como a "festa da palavra marginal" e acrescenta que a moderna ficção angolana:

(...)se caracteriza, sobretudo, pelo fato de nela se observar a luta do escritor contra a palavra "alheia", de cujo domínio ele procura se libertar. Há um movimento de apropriação daquilo que ao produtor 
convém aproveitar e uma superação do que não lhe interessa esteticamente. (PADILHA, 2007, p. 228)

Deste modo, num sentido bastante próximo do protagonismo e da criatividade dos transculturadores latino-americanos analisados por Rama, também interessa aos escritores angolanos, e indo mais além, aos escritores das literaturas insurgentes nos processos de libertação colonial de países africanos no século XX, que a linguagem de seus textos seja a expressão ou a palavra que lhe permitam singularizar-se e estas são encontradas na configuração de uma linguagem que sobrepõe as temporalidades de presente, passado e futuro, ou seja, escritores como Luandino Vieira utilizam-se da língua portuguesa, no entanto, buscando recuperar uma visão de mundo que seja angolana, na dinâmica de passado, presente e futuro que acabamos de mencionar e que podemos sintetizar, valendo-nos, mais uma vez, das contribuições de Padilha:

Outra questão ligada às práticas ancestrais narrativas de resistência é o uso literário das línguas nacionais [...] No enfrentamento do velho (autoctonia angolana) e do novo (ordem de poder colonial portuguesa), ganha um relevo especial o lugar antagonicamente central e periférico que ocupam tais línguas, do ponto de vista, respectivamente, do colonizado e do colonizador

$[\ldots]$

Estas [as línguas nacionais] deixam de ser um objeto dicionarizável apenas, para renascerem como línguas vivas, reinserindo-se no universo do discurso literário com a mesma pujança original que tinham nos contextos sócio-lingüísticos autóctones". (PADILHA, 2007, pp. 27-28)

Não pretendemos, aqui, estabelecer conexões ou filiações indistintas entre as reflexões de Rama e os estudos das literaturas africanas de língua portuguesa, em lugar disso, o recurso às reflexões de Padilha corroboram no sentido de notar como a experiência histórica da colonização a que passaram os países da América Latina e os países africanos levanta problemas bastante próximo à configuração de seus 
sistemas literários, embora com respostas e proposições diferenciadas.

Retomaremos com maior vagar esta questão numa análise mais detalhada dos contos cotejados, por ora, partiremos à segunda operação transculturadora desenvolvida na conceituação de Rama: a estruturação literária.

Neste ponto, o autor afirma serem ainda mais complexas as investidas estéticas dos transculturadores com relação aos aspectos linguísticos, ou seja, no momento em que a narrativa moderna (com Joyce e Virginia Woolf, por exemplo) direcionava-se a inovações que se distanciavam das narrativas tradicionais (ancoradas no naturalismo do século XIX), os transculturadores fariam ainda um recuo às formas tradicionais de narração. Em lugar do mónologo interior (a nomeada técnica do stream of consciousness), os autores optarão pelo mónologo discursivo, muito próximo do relato oral, constituindo, assim, um:

Esfuerzo de construir una totalidad dentro de la cual se recuperan formas inconexas y dispersivas de la narración rural pero ajustadas a una unificación que ya procede del impacto modernizador. (RAMA, 1987, p. 47)

Deste modo, a focalização da estruturação narrativa empreendida por Rama passa, necessariamente, por um diálogo com questões relacionadas à oralidade, ou melhor, dos caminhos percorridos pelos autores para dar vivacidade e centralidade a este elemento cultural dentro de suas narrativas.

Embora a categorização do crítico separe estas instâncias da língua e da estruturação narrativa na organização de seu texto, não escapamos da leitura sem uma noção de totalidade e de inter-relação entre os termos. Assim, concomitante ao esforço criativo, estaria a noção de eliminação das distâncias entre o narrador e o universo narrado. 
Proposta de leitura que analisa o mesmo problema encontramos na conceituação do "narrador cúmplice" proposta por Rita Chaves para o romance angolano. Tal narrador seria aquele que consegue, coerentemente, realizar a incorporação da diferença local como matiz narrativa, deste modo, a despeito do narrador de $A$ vida verdadeira de Domingos Xavier, de Luandino Vieira, a autora irá afirmar:

\begin{abstract}
Penetrando no interior da matéria ficcional, o narrador de Luandino suaviza da distância que poderia haver entre o sujeito que escreve e o mundo daqueles sobre os quais tece seu texto. Mesmo sob a forma de uma sutil terceira pessoa, esse narrador está identificado culturalmente com o universo narrado, numa atitude que, graças ao contexto especial daquele momento, acaba por imprimir também a adesão ideológica às propostas ali sugeridas e até veiculadas de maneira mais clara. (CHAVES, 1999, p. 169)
\end{abstract}

Cabe aqui, um breve parênteses para retomar o paradigmático texto de Walter Benjamin, "O Narrador", o qual na elaboração do conceito de experiência, pontua que as melhores narrativas escritas seriam aquelas que menos se distinguissem dos relatos orais, aos mesmo tempo em que anuncia a morte da arte de narrar, pela falta de espaço à experiência no advento da modernidade. Assim, retomando às proposições de Rama, em contraponto a Benjamin, nos fica mais evidente a ambiguidade e as tensões que se instauram no trabalho narrativo dos transculturadores.

A última instância operacional analisada nas narrativas transculturadoras por Ángel Rama é a cosmovisão, compreendida como espaço no qual se assentariam valores e ideologias, sendo, por seu turno, o nível de transculturação mais resistente a ceder às mudanças da modernização homogenizadora pautada em padrões "estrangeiros" 
Como resposta estética, o crítico destaca o fato dos transculturadores colocarem em xeque o discurso lógico-racional que vinha dirigindo a literatura (XIX), levantando nesta operação o fato de que assim, uma vez mais, questionar este discurso implicaria em diminuir as distâncias entre a estrutura discursiva e os materiais compositivos da obra: "a quebra deste sistema lógico deixa em liberdade a matéria real pertencente à América Latina e permite apreciá-la em outras dimensões"8 (RAMA, 1987, p. 52)

As outras dimensões apreciativas da matéria latino-americana são compreendidas por Rama como uma reorientação do mito, que deixaria de ocupar o espaço meramente fabulativo e recuperaria o vigor das sociedades tradicionais, atuando como história "verdadeira". A aparente irracionalidade (pejorativa) a que poderiam ser associados tais procedimentos, é na verdade, para Rama, a contribuição rica e imprevisível dos transculturadores:

Por lo tanto, la respuesta de la desculturación que en este nivel de la cosmovisión y del hallazgo de significados promueve el irracionalismo vanguardista, sólo en apariencia parece homologar la propuesta modernizadora. En verdad, la supera con imprevisible riqueza, a la que pocos escritores de la modernidad fueran capaces de llegar: al manejo de los "mitos literarios", opondrá el "pensar mítico (RAMA, 1987, p.55)

Da citação anterior, cumpre-nos ainda destacar, a noção de "pensar mítico" proposta por Rama, que seria a maneira pela qual o autor maneja as fontes da oralidade, associando-as a novas significações, e nisto Rama aponta estar o logro dos transculturadores, que seja o de oferecer diferentes atualizações e apropriações do mito, retirando-o de um fundo ambíguo para formular não menos ambíguas e

8 No original: "la quiebra de este sistema lógico deja en libertad la materia real perteneciente a América Latina y permite apreciarla en otras dimensiones" 
distintas associações com o presente enunciativo.

Detemo-nos mais demoradamente sobre as conceituações de Rama por que elas nos permitiram formular algumas perguntas aos textos analisados, bem como, ofereceram a possibilidade de lançar um olhar comparativo aos textos que não estabelecesse hierarquias (no caso, verificando possíveis influências de Rosa em Vieira), mas, em lugar disso, dispor deste arsenal teórico latino-americano em diálogo com aquele destinado às produções africanas, para verificar como experiências históricas relativamente comuns podem apontar para conflitos estéticos também comuns, embora singulares e convergentes ao mesmo tempo. ${ }^{9}$

Remontando às aproximações que foram feitas inicialmente nas leituras das obras ficcionais elegidas para este cotejo, encontra espaço para discussão, após o acompanhamento do percurso da teorização da transculturação em Rama, a verticalização no universo infantil, melhor dizendo, uma análise que privilegiou nos escritores uma perspectiva voltada para os tempos da infância, como rememoração e, por vezes, na dissolução destas distâncias temporais.

Tal universo, o da infância, mostra-se nos contos dum e doutro autor como espaço fértil para análise tanto da estruturação literária, como para a observação das soluções estéticas encontradas por eles para um trabalho que evidenciasse a veia transculturadora.

9 A este respeito é interessante observar as contribuições de Ana Pizarro para o pensamento de um discurso emancipatório latino-americano, em que a pesquisadora frisa tanto a configuração histórica e social que confere originalidade às letras do continente, bem como pontua não ser esta uma "exclusividade" de tal contexto social: "El carácter conflictivo no es patrimonio sólo de nuestras literaturas: tique que ver más bien com culturas que surgen del parto colonial y que em su independización operan com mecanismos comunes tendientes a esclarecer su subjetividad diferencial"(PIZARRO, 1994, p. 24) 


\subsection{A criança, a palavra: caminhos da estruturação narrativa}

Daremos continuidade a este capítulo balizando o percurso de análise proposto para as obras, partindo de uma justificação do universo infantil como o espaço mítico das recriações, a princípio, no plano da linguagem, para posteriormente, pela caracterização das crianças presentes nas obras mapear os ecos e os diálogos dos autores com o contexto sócio-histórico de produção das suas obras.

O primeiro texto que julgamos importante para tal proposta de leitura é um ensaio de Henriqueta Lisboa, que analisará o motivo infantil na obra de Guimarães Rosa e como ele se manifesta temática e esteticamente na escrita rosiana.

Para a autora, ademais das personagens que povoam os contos, existiria uma lógica infantil a regular a construção do texto, como é possível inferirmos no seguinte trecho:

A alegria inexplicável das cousas amanhecentes, a descoberta da natureza, o despontar do pensamento através de palavras anteriores à lógica, a trepidação dos diálogos, o fluxo e refluxo dos monólogos, o jogo das metáforas [...], tudo isso remonta à infância do autor, tudo isso demonstra a sua faculdade de prolongar a infância. (LISBOA, p.171, 1983).

Temos assim uma infância (re)construída pela palavra, como se este prolongamento da infância fosse possível à medida em que a representação desta lógica se fizesse pelo texto literário.

Discussões como a de Henriqueta Lisboa corroboram no sentido da escolha que fizemos ao tratar a (re)criação nos termos da transculturação em Guimarães 
Rosa e Luandino Vieira, ou seja, tomá-la pelo viés da infância. Assim, no escopo das construções míticas, a infância nos textos, mais que motivo, é estruturante da obra e da tessitura das estórias.

E na mesma senda das proposições da análise feita por Henriqueta Lisboa, temos as contribuições de Willi Bolle, o qual define a criança como o símbolo da transgressão e da tensão na linguagem rosiana, na medida em que ironiza os sentidos da língua:

A criança, que aparentemente não entende a significação das palavras, intui a possibilidade de utilizá-las ironicamente, expressando assim uma postura de narrador, que se coloca ao lado de personagens iletrados para pôr em dúvida a linguagem "certa" (BOLLE, p. 88, 1973)

O que nos aponta Bolle é bastante presente no caso de Primeiras Estórias, em boa parte das narrativas em que as crianças aparecem, estas parecem não "compreender" os significados das palavras. Contudo, a partir desta incompreensão, buscarão tanto os sentidos latentes, como os perdidos, numa lógica associativa bastante comum à época da infância.

Um outro estudo bastante paradigmático e que figurou os referenciais para a execução deste trabalho é o de Benedito Nunes, importante estudioso da obra de Guimarães Rosa, num ensaio sobre a temática do amor na obra do escritor mineiro.

Segundo a leitura do crítico, as crianças, na obra de Guimarães Rosa poderiam ser encaradas como fazendo parte de um período de maior receptividade ao meio no qual vivem, configurando, assim, um tempo de sabedoria, como nos afirma no trecho a seguir: 
Esses personagens - o Menino, a Menina, o Jovem - dados a encantamentos e sortilégios, munidos de dons extraordinários, e que podem ter das coisas uma visão mais completa do que a comum, pertencem a uma só família mítica. A infância ou a juventude é neles um estado de receptividade, de sabedoria inata, e tem duplo sentido: por um lado, remoto e nebuloso passado, que se confunde com as origens, e por outro, prenúncio de um novo ser, ainda em esboço, que advirá do que é humano e terrenal. (NUNES, p. 127, 1994)

Sobre esta transposição de uma realidade carente de linguagem, de criação, a um plano poético transformador, um ensaio, que pela abordagem realizada, não poderia deixar de nortear este percurso de leitura é "Céu, inferno", artigo de livro homônimo no qual o autor estabelece uma leitura dos sertões e de suas gentes a partir da análise de Graciliano Ramos e Guimarães Rosa, e mais especificamente nas obras Vidas Secas e Primeiras Estórias.

Neste ensaio Bosi irá contrapor um olhar determinista e externo associado a Graciliano Ramos, e à escassez (secura) de linguagem de suas personagens, como se a opressão lhes destituísse a fala, com uma visão "de dentro" das personagens proposta por Rosa, como se a este último pudéssemos associar um mergulho nas crenças e na espiritualidade destes sertanejos. Assim, ele dirá acerca desta proposta rosiana: "O escritor teria preferido pôr-se à escuta das vozes singulares que saem da boca dos viventes sertanejos, tomando-as por inspiradas, belas e verdadeiras em sim mesmas (BOSI, 1998, p. 22).

Para o crítico, através de uma reelaboração da linguagem, e do poder criador atribuído à palavra, é como se as personagens saíssem de um estado de letargia, para com a intervenção da fábula e do mítico escaparem à esta realidade: 
Muitas personagens das Primeiras Estórias acham-se privadas de saúde, de recursos materiais, de posição social e até mesmo do pleno uso da razão. Pelos esquemas de uma lógica social moderna, estritamente capitalista, só lhes resta esperar a miséria, a abjeção, o abandono, a morte. [...] Apesar disso, os contos não correm sobre trilhos de uma história de necessidades, mas relatam como, através de processo de suplência afetiva e simbólica, essas mesmas criaturas conhecerão a passagem para o reino da liberdade. [...] Quando toda grande modificação vem de fora, o "de dentro" não precisa desenvolver nenhuma razão de previsibilidade de longo alcance, nenhum projeto que amarre fins e meio, a não ser aqueles que cabem no dia-a-dia da sobrevivência. No mais, que a alma almeje o que quiser. A ordem do transcendente abre horizontes sem fim e, no devir da fantasia, alguma coisa sempre pode acontecer. (BOSI, p. 25, 1998)

Assim, percebemos que nas estórias de Guimarães Rosa há uma superação do estado de carência das personagens, através do "devir da fantasia". As crianças, com seus pensamentos ainda na "fase hieroglífica", são as representantes de uma linguagem nova, que irá buscar nas fases mais remotas, na infância da palavra, maneiras de transformar o cotidiano, de retirá-los a uma paralisia onde parece "não acontecer coisa nenhuma”.

E como a pretensão é a de trazer ao trabalho, juntamente com a caracterização das personagens infantis, os contornos do projeto estético do escritor reproduzimos abaixo uma fala de Luandino para o Jornal de Letras, Artes e Idéias, de Lisboa sobre a questão da presença da oralidade a redefinir a linguagem que utilizaria em sua produção ficcional:

[...] penso que o primeiro elemento da cultura angolana que interferiu com a escrita, segundo a norma portuguesa, foi a introdução da oralidade luandense no meio do discurso da norma portuguesa... mas depois, quando entramos na luta política pela independência do país, que foi feita em nome das camadas que não tinham voz - e se tivessem não podiam falar, e se falassem não falariam por muito tempo... -, foi aí que os escritores angolanos resolveram dar voz àqueles que não tinham voz e, portanto, escrever para que se soubesse o que era o nosso país, se soubesse qual era a situação 
do país e, desse modo, interferirem de maneira a modificarem essa situação [...]. ${ }^{10}$

Em Luandino Vieira, as crianças também recriam a realidade, pois a brincadeira e a viagem proposta por Turito (o menino alheio, envolto de atmosfera mágica), em "Lá em Tetembuatubia", por exemplo, vai envolvendo a todos num ambiente onde as adversidades do meio (musseques de Luanda, as regiões periféricas da cidade), vão sendo superadas pela perspectiva de se chegar ao lugar mágico, Tetembuatubia, criado somente com a força das palavras de Turito, com sua capacidade de fabulação, de inventar mundos.

No entanto, à medida em que vamos nos debruçando um pouco mais sobre a estória, visualizamos, nesta criação em tons de brincadeira, crianças que durante um processo lúdico acabam (re)criando não apenas uma fala, mas uma maneira de enxergar o mundo, o que nos permite afirmar que além de se tratar de uma recriação linguística, pode-se falar também de uma ideologia que pontua estas recriações, ou seja, podemos recuperar novamente a ideia de se tensionar o discurso dominante, para se criar uma fala mais próxima de sua realidade natural e social.

Esta perspectiva está calcada numa visão em que a linguagem se configura como mediadora das relações entre o sujeito e o meio que o cerca, como se esta recuperação da capacidade de criação do tempo da infância implicasse, por vontade e consequência, num projeto de libertação: "Vida assim já é o nunca mais ser, tudo

10 In "Um escritor confessa-se... ". Entrevista de Luandino Vieira publicada no Jornal de Letras, Artes e ldéias, de Lisboa, em 9/5/89, p. 10. 
só o estar cá - antiga unidade escrava virando misturas forras". (VIEIRA, P. 31, 2005)

Deste modo, quando pensamos a recriação da linguagem em No antigamente, na vida associada a uma postura marcadamente política, encontramos, muito provavelmente, uma especificidade do texto e do contexto angolano, já que para uma sociedade como Angola, com sua independência tardia, a presença do colonizador era ainda realidade, e a auto-afirmação e a construção de uma identidade nacional potencializam esta necessidade de se aproximar o texto ficcional de um discurso que buscasse definir a angolanidade.

Feito este breve panorama onde procuramos levantar como a (re)criação manifesta-se tanto em Vieira, como em Guimarães Rosa, configurando o eixo comum que é a sua representação na figura da criança, passaremos, agora, a trabalhar os escritores isoladamente, para que as singularidades destas escritas que apareceram brevemente nesta primeira parte se evidenciem e se intente, assim, alcançar os objetivos propostos para este trabalho.

\subsection{Guimarães Rosa: a missão de harmonizar forças contrárias}

Nisso, aliás, como em tudo o mais, o que se passa aqui é mero reflexo do que vai pelos países cultos. A palavra de ordem é: construção, aprofundamento, elaboração cuidadosa e dolorosa da "matéria-prima" que a inspiração fornece, artesanato. (GUIMARÃES, 1972, p. 132)

O texto a que nos servimos de epígrafe é um fragmento da correspondência entre Guimarães Rosa e Vicente Guimarães, em que o escritor posiciona-se em relação aos aportes estrangeiros, sobretudo das vanguardas europeias, como fontes 
para uma reflexão mais aprofundada do que chama de "construção literária".

O que acaba por se destacar tanto neste trecho, como na continuidade da argumentação de Rosa é que para o escritor haveria a necessidade de que a literatura brasileira não se valesse de uma língua portuguesa fixa e permeada por lugares comuns, mas que estivesse preocupada com uma linguagem representativa e diferenciada.

Somada a estas investidas das vanguardas, o autor ainda assumiria como de profunda riqueza para a construção de sua linguagem literária o que ele chama de "sabedoria linguística" de sua região - referindo-se ao sertão mineiro - e arcaísmos presentes, por exemplo, no português utilizado na Idade Média.

Pois bem, todas estas fontes de composição para a estruturação de seus textos trazem em si uma conflituosidade que o autor para ter assumido como missão harmonizar em sua obra, sem escapar, certamente, às ambiguidades de tal intento; esta visão vai no sentido de descondicionar hábitos verbais, expressão que tomamos emprestado a Paulo Rónai ${ }^{11}$, que o autor julga serem sinais de um atraso nas letras brasileiras, cuja entrada na modernidade dependeria de uma criativa conjunção de todas as "forças" relacionadas às fontes citadas.

A concepção de descondicionar hábitos verbais nos parece, portanto, caminho bastante profícuo para organizar uma leitura da linguagem em Guimarães Rosa por duas razões centrais: a primeira delas é que o sentido de descondicionar guarda em si próprio a noção de uma acomodação, de um condicionamento anterior,

$11 \mathrm{O}$ autor atribui esta função à linguagem rosiana na discussão realizada no texto: "Os vastos espaços" (1966), utilizado como prefácio à edição de Primeiras Estórias utilizada para o presente trabalho. 
podendo relativar a concepção do novo, do inédito na linguagem de Rosa e, ao invés disso, apontar para o trabalho com uma matéria pré-existente, ou seja, tornar evidente a convivência no texto do moderno e do arcaico; e a segunda, decorrente da referida oposição, é que tal abordagem permite escapar às armadilhas do texto rosiano, que sejam as de situar-se somente no plano estético e de deixar de lado o diálogo profícuo e ambíguo que o autor estabelece com o pensamento brasileiro, no que tange aos caminhos e descaminhos entre tradição e modernidade na definição e/ou construção da nacionalidade brasileira.

Esta segunda dimensão será tratada em outro capítulo, por ora, nos deteremos na primeira, no sentido de compreender, com todas as limitações que se impõem a esta tarefa, a organização da linguagem em Primeiras Estórias.

Ainda segundo Paulo Rónai, Rosa irá fazer com a linguagem o que todos os ficcionistas fazem com a realidade, ou seja, utilizá-la de acordo com as suas intenções, "tratando suas parcelas como peça de um mosaico" (p. 29). Assim irá o autor explorar a expressividade destas partes, articulando um material visto e observado com o seu profundo conhecimento não só da língua portuguesa, mas de uma série de idiomas.

A este respeito seria interessante acompanhar de perto o que o crítico Luiz Roncari definirá como as fontes da composição da visão de mundo e da matéria ficcional de Guimarães Rosa:

(...) uma empírica, dada pela vivência direta da região e do país; outra mítica e universal, adquirida na leitura da literatura clássica e moderna; e outra nacional, apoiada não só na nossa tradição literária, mas também nos velhos e novos estudos e interpretações do Brasil, efervescentes a seu tempo (RONCARI, 2004, p. 17) 
Para Roncari a obra de Guimarães poderia ser efetivamente lida e interpretada, considerando todos estas dimensões da composição de seu texto, segundo esta visão, somente assim, se facultaria a capacidade de penetrar em todas as camadas do texto.

Opondo-se, mas também, complementando-se à atmosfera quase mágica apontada nos contos de Primeiras Estórias, ainda mais confirmada pela postura crente e anti-intelectual que o autor tenta imprimir à sua produção, como nos afirma Kathrin Rosenfield, está localizada uma linguagem sinônimo de intensa reflexão e muito mais planejada que intuída: "Reperdida a remembrança, a representação de tudo se desordena: é uma ponte, ponte - mas que, a certa hora, se acabou, parece' que. Luta-se com a memória" (ROSA, 2001, p. 104).

Neste trecho de "Nenhum, nenhuma" desnuda-se esta soma entre o intuído e o refletido. O narrador, em primeira pessoa, a partir do ponto de vista do adulto, procura rememorar e construir a linguagem da infância sem, contudo, deixar entrever a racionalidade deste processo. É travada, assim, uma luta entre o que se recorda e o que se pretende expressar, da desordem dos variados materiais de sua composição literária, o autor assume este papel de estabelecer as pontes, organizando-as.

\subsection{Luandino Vieira: alternativas do escritor colonizado}

Um dos problemas colocados ao escritor colonizado é a ambiguidade linguística, como bem aponta Memmi. Segundo o autor, o escritor colonizado traria 
em sua própria figura todas as possibilidades de ser do colonizado.

No decorrer de seu livro, Retrato do colonizado precedido pelo retrato do colonizador, a situação colonial é definida essencialmente como um fenômeno de usurpação, ou seja, o colonizador irá cunhar para si uma gama de privilégios, os quais, justificados por uma missão civilizadora de cunho cultural e moral que na verdade, cumpre o único propósito de aviltar o colonizado, irá expropriar a humanidade deste último e concomitantemente os bens culturais que a ratificam.

Dentre estes bens culturais, irá nos interessar para a discussão aqui proposta, a linguagem, ou mais especificamente, as línguas autóctones. Sobre este aspecto, Memmi irá afirmar com veemência a difícil tarefa de um escritor colonizado: por um lado sua língua, a partir da colonização, lançada ao desprestígio e ao apagamento, não Ihe serviria ao ofício senão para lhe condenar a uma escrita sem interlocutores, pois a grande massa colonizada não teria acesso, ou melhor, condições para a decodificação dessa língua passado ao registro escrito; por outro lado, utilizar a língua do colonizador implicaria tomá-la de empréstimo e, sendo assim, seu interlocutor seria aquele contra a quem se volta, gerando o problema de escrever para um público que não lhe interessaria. Diante dessa situação, o autor trará a proposição de duas alternativas:

(...) pelo esgotamento natural da literatura colonizada, as próximas gerações nascidas na liberdade, escreverão espontaneamente na sua língua recuperada. Sem ir tão longe, outra possibilidade pode tentar o escritor: decidir-se a pertencer totalmente à literatura metropolitana. Deixemos de lado os problemas éticos suscitados por tal atitude. É então o suicídio da literatura colonizada. Nas duas perspectivas, só o prazo diferindo, a literatura colonizada de língua européia parece condenada a morrer jovem. (MEMMI, 1979, p. 100) 
As alternativas levantadas por Memmi nos parecem bastante lúcidas, no entanto, o que difere, deslocando a expressão usada pelo autor, é a trajetória, para nos atermos ao contexto estudado, da literatura angolana. Fato este, que não permite que nos furtemos de matizar a problemática, buscando mapear os caminhos que os autores encontraram para sua literatura, e mais especificamente, as opções estéticas e políticas de Luandino Vieira.

Sendo assim, para além do que aponta Memmi, que seja o desaparecimento da literatura colonizada em língua europeia e o consequente surgimento de produções em línguas autóctones, ou ainda, o precoce desaparecimento dessas literaturas, consideramos o viés tomado por José Luandino Vieira emblemático para vislumbrar as possibilidades para escapar a esta morte eminente da literatura em solo colonizado.

Tanto em seus textos literários como em suas reflexões sobre o fazer literário, a questão linguística surge como uma preocupação capital a Vieira. Em contraponto ao que Memmi denominará como empréstimo, com a decorrente atmosfera de dívida para com a metrópole, o autor vê a língua portuguesa como um "despojo de guerra", a partir do qual irá realizar um intenso trabalho com a inserção de elementos da cultura angolana, a fim de construir não uma nova língua, mas uma linguagem que pudesse trazer ao corpo do texto os anseios de uma identidade em construção, ou ainda, lançando mão das reflexões de Homi Bhabha, uma produção onde:

(...) a questão da identificação nunca é a afirmação de uma identidade pré-dada, nunca uma profecia autocumpridora - é sempre a produção da imagem de identidade e a transformação do sujeito ao assumir aquela imagem (BHABHA, 2003, p. 76) 
Assim, a obra de Luandino Vieira expressa esta preocupação em construir, a partir da tomada da língua portuguesa, uma linguagem que pudesse refletir esta imagem de identidade que se buscava para o povo angolano, no escopo das lutas de libertação do país.

Sua escrita torna-se, deste modo, comprometida a tensionar não só a língua, mas o discurso colonial, buscando encenar no texto as personagens deste universo em conflito, que é a colônia, e vislumbrando assim, que estas mesmas personagens possam sair da imobilidade e desfazer a "amnésia cultural" que lhes é imposta com a colonização, através da reconstrução de um passado obliterado, na perspectiva e nos termos do tempo presente, com vias a identificar-se com o futuro de liberdade ansiado naquela conjuntura, como podemos observar uma vez mais em Bhabha:

O ato de rememoração (seu conceito de recriação da memória popular) transforma o presente da enunciação narrativa no memorial obssessivo do que foi excluído, amputado, despejado, e que por esta mesma razão se torna um espaço unheimlich para a negociação da identidade e da história (BHABHA, 2003, pp. 274-275)

No momento em que fala dessa rememoração, Bhabha está discutindo a obra de Toni Morrison, e de como as intencionalidades e os propósitos de uma construção identitária, observadas no texto da escritora afro-americana, emergem de um "entretempo", onde haveria a negação da continuidade da narrativa, bem como de um conforto cacofônico das palavras.

Estas reflexões nos interessam no sentido de situar a linguagem de Luandino Vieira neste entre-tempo, que assume a impossibilidade da continuidade, da harmonização, dadas as rupturas já mencionadas do sistema colonial, mas que ao mesmo tempo irá trazer este tempo passado, o "lá" como repetidas vezes aparece 
em suas narrativas, para este presente de cortes, de tensão.

Aproveitando-nos do contexto das produções de literaturas afro-americanas, trazido pelas reflexões de Bhabha, mas acreditando, também, ser o diálogo bastante profícuo, no sentido de ampliar perspectivas distintas, embora confluentes sobre a mesma problemática, qual seja o impasse linguístico colocado aos grupos subjugados, nos valeremos da leitura de um interessante artigo de bell hooks ${ }^{12}$ : "Linguagem: ensinar novas paisagens/novas linguagens", como um disparador à ampliação de possibilidades de respostas ao impasse que mencionamos há pouco.

Nele, a autora relaciona a apologia ao uso do inglês padrão como uma forma de opressão a outras variantes da língua, além de observar as relações de poder, bem como as hierarquias raciais e sociais advindas delas e que, por fim, acompanham a disseminação da modalidade standard da língua.

Assim, o que acaba por nos reter nossa atenção no artigo e onde encontramos confluências com a leitura aqui proposta é uma preocupação que aparece repetida vezes: a necessidade dessa língua opressora e a inserção de elementos culturais não-hegemônicos como forma de tensioná-la e torná-la mecanismo de resistência:

Imagino, então, as pessoas ouvindo pela primeira vez o inglês como "língua do opressor" e então reouvindo-a como um local potencial de resistência. (...) Possuindo a língua compartilhada, povos negros poderiam encontrar de novo uma maneira de fazer comunidade, e um sentido para criar a solidariedade política necessária para resistir. (HOOKS, 2008, p. 859)

12 A escrita em letras minúsculas é opção da própria autora para assinar seus textos, adotada a partir de sua primeira publicação (And There We Wept, 1978), justificada pela autora pelo fato de que a substancialidade de seus textos seria mais importante do que quem era ela: "he believes that what is most important is the "substance of books, not who I am."'. In: WILLIANS, Heather. bell hooks Speaks up. 
Destacamos deste trecho e da argumentação que segue uma orientação fundamental ao texto de hooks e também à maneira como vimos apontando ter tomado Luandino Vieira a língua portuguesa, a de uma não passividade neste uso, postura que permitirá a conversão de um mecanismo de dominação em arma de luta:

Nas bocas de africanos negros no chamado novo mundo, o inglês foi alterado, transformado e tornou-se fala diferente (...). Eles colocaram junto suas palavras de maneiro que o colonizador tivesse que repensar o significado da língua inglesa. (HOOKS, 2008, p. 859)

E um pouco mais adiante:

Para cada uso incorreto de palavras, para cada colocação incorreta das palavras, era um espírito de rebelião que reivindicava a língua como local de resistência. (...) O poder dessa fala não é simplesmente possibilitar a resistência à supremacia branca, mas é também fabricar um espaço para a produção cultural alternativa e epistemologias alternativas - diferentes maneiras de pensar e conhecer que foram cruciais para criar uma visão de mundo contrahegemônica. (HOOKS, 2008, p. 860)

Salvas as distinções contextuais, observamos que tanto a imposição de uma norma culta da língua inglesa em contraponto com as apropriações e intervenções da população negra, discutidas no texto de hooks, como as tensões e ambiguidades da imposição linguística da empresa colonial em território angolano, problematizada na obra de Luandino Vieira, guardam em comum estratégias destes povos subjugados no que se refere à resistência e à (re)significação deste uso.

Encontramos aí, similaridades muito próximas das considerações que faz Stuart Hall quando compara o caráter "impuro" e híbrido das culturas diaspóricas caribenhas, aproximando-as também dos momentos de contestação anti-coloniais: 
"Os momentos de independência e pós-colonial, nos quais essas histórias imperiais continuam a ser vivamente retrabalhadas, são necessariamente, portanto, momentos de luta cultural, de revisão e de reapropriação" (HALL, 2003, p. 34).

Retomando o texto de bell hooks, para quem além de oposição a uma supremacia branca, esta resistência pela linguagem significava também construir espaços para formações culturais alternativas, e acrescentaríamos aqui, também "alterativas", a ficcionalização da fala dos musseques converte-se no mecanismo, para Luandino Vieira, da representação de novos espaços identitários, ou seja, deixa de ser a língua do opressor para, em posse de outra orientação e sentidos vários, tornar-se a língua em alguma medida condizente com o projeto de homem novo ${ }^{13}$ angolano, pretendido pelo MPLA (Movimento pela Libertação de Angola) e do qual José Luandino Vieira foi militante, necessário ao ideário de país que se deseja a partir das lutas de libertação, ou seja, como acertadamente afirma Fanon, a descolonização "introduz no ser um ritmo próprio, trazido pelos novos homens, uma nova linguagem, uma nova humanidade" (FANON, 2005, p. 53).

Em consonância ao que afirmamos anteriormente sobre os ecos da formação do homem novo na linguagem de Luandino, está o caráter pedagógico no texto de hooks, que traz deste seu título ${ }^{14}$ a noção de linguagem ensinando novos mundos por novas palavras. A linguagem torna-se, assim, o palco de encenação da diferença, da singularidade, como a alicerçar as bases para a conquista dos espaços negados pelo colonialismo.

13 O homem novo é aqui tomado, num sentido amplo, na acepção marxista do termo, ou seja, o homem novo seria aquele, imbuído do espírito revolucionário, que conseguisse mobilizar seus conhecimentos no sentido de alcançar as transformações sociais necessárias à nova Angola, pretendida com a descolonização.

14 No original: Language. Teaching New Worlds, New Words 
Entre as reflexões de Luandino Vieira sobre a sua produção estética, há uma fala bastante emblemática do que vimos discutindo até então, proferida em entrevista em que o autor fala sobre a escrita de Luuanda, livro de contos que inaugura a fase do autor onde esta preocupação se evidencia com maior vigor:

E como estávamos numa fase de alta contestação política - e um dos elementos dessa contestação política do colonialismo era afirmar a nossa diferença cultural, mesmo na língua - um bichinho qualquer soprou-me a dizer-me: "Por que é que tu não escreves em língua portuguesa de maneira que nenhum português perceba!

Destacando, sobretudo, dois elementos da fala de Luandino Vieira, a saber: contestação e diferença cultural, é que voltamos ao texto de Memmi. Na segunda parte de seu retrato do colonizado, quando constrói a resposta deste ao colonialismo, dois momentos se coadunam com a fala acima reproduzida: a recusa do colonizador e a afirmação de si.

Verificada a impossibilidade de assimilação, Memmi se volta uma vez mais à clave da ambiguidade, ou seja, nem se verificaria no colonizado uma irrestrita vontade de assimilação, nem se operaria uma rejeição total do modelo. Em outras palavras, usa-se a princípio uma linguagem comum ao colonizador (escrever em língua portuguesa) que no contexto da luta anti-colonial acabará se voltando contra este último (de maneira que nenhum português a perceba).

Com isso, o colonizado parte à afirmação de si, condicionada pela situação colonial, que já não Ihe permite enxergar-se como um homem geral, portador de valores universais, mas que se afirme com base em sua singularidade (afirmar nossa diferença cultural).

Outra vez durante a construção de seus retratos, Memmi, na relação deste 
processo de contestação ao colonialismo e afirmação de identidades, tratará da utilização ou não das línguas autóctones. E, mesmo reconhecendo as dificuldades e limitações deste uso, o autor irá, ao mesmo tempo, reconhecer a necessidade do colonizado em utilizar as línguas autóctones durante este caminho de "retorno" ao que lhe é especificador, mesmo com dificuldades de organização, decodificação e sistematização das mesmas, o seu uso implicaria uma reviravolta cultural, e mais do que a compreensão, importaria o dado de resistência: "O importante agora é reconstruir seu povo, seja qual for a sua autêntica natureza, refazer sua unidade, comunicar-se com ele e sentir que lhe pertence" (MEMMI, 1979, p. 116).

Luandino Vieira, assim, torna a tônica de sua linguagem a busca dessa unidade na fragmentação, e ela se fará no desejo da construção de novas solidariedades, encontrada na utilização da fala dos musseques, vivamente expressa com as interferências, modificações e reorientações discursivas do quimbundo. ${ }^{15}$

15 O quimbundo é umas das línguas autóctones faladas em Angola e seu uso se dá, principalmente, na região da capital angolana, Luanda, espaço privilegiado da ficção de Luandino Vieira. 


\section{2 - A palavra e as imagens de identidades nacionais: estabelecendo o percurso das diferenciações}

\subsection{Imagens das identidades nacionais na literatura}

Segue-se que a nação não é apenas uma entidade política mas algo que produz sentidos - um sistema de representação cultural. As pessoas não são apenas cidadãos/ãs legais de uma nação; elas participam da ideia da nação tal como representada em sua cultura nacional. (HALL, 2003, p. 48)

Ao iniciarmos o percurso interpretativo deste trabalho pelo viés da (re)invenção, procurando não nos restringirmos a um mapeamento linguístico das investidas estéticas dos escritores, mas, em seu lugar, localizar os textos literários num debate que, tomando-os como manifestações culturais, intentasse situá-los sócio-historicamente, não poderia nos escapar a noção de que estando preocupados com uma elaboração estética em consonância com um "esforço independentizador"- em expressão de Ángel Rama -, estes escritores colocariam também os seus textos, de alguma maneira, a serviço das identidades.

Falar em identidades na ficção de escritores pertencentes a países de passado ou presença colonial, aponta para o fato de que no jogo destas identidades, aquelas que se relacionam a uma cultura ou imaginação nacional não poderiam escapar, ou seja, da estruturação literária muitas são as imagens que emergem como significantes destas identidades em construção: 
portuguesa, nos quais o sentido político se constrói por um efetivo trabalho com a linguagem, que se faz inventiva e ágil, criadora de transgressões. A subversão do código, insistindo em evidências que fazem do português uma língua modelada pelos ritmos africanos, alude, por outros matizes, aos complexos processos de construção de nacionalidades ainda em formação. (FONSECA, 1999, p. 156)

Benedict Anderson inicia Comunidades Imaginadas por destacar que condição nacional seria um produto cultural que surgiu, em fins do século XVIII ${ }^{16}$, a partir de uma "destilação espontânea" do cruzamento de diferentes forças históricas. No entanto, apesar da efemeridade que possa guardar o termo "destilação", o autor frisa que estes produtos acabaram por se tornar modulares e, assim, puderam ser transplantados a contextos diversos, bem como se incorporarem a diferentes projetos ideológicos e políticos.

Dentro dos propósitos deste trabalho nos interessa a abordagem que o autor realiza, tomando os produtos supra-citados sob a insígnia de "comunidades imaginadas", as quais, é relevante pontuar, são construídas a partir de dois movimentos principais: as solidariedades entre os indivíduos a construir os laços comunitários necessários ao sentimento de pertencimento comum e a operacionalização da memória que irá determinar o que deve ser lembrado e/ou esquecido na imaginação fundadora de tais comunidades.

Entre o lembrar e o esquecer surgem, assim, forças distintas que concorrem e se somam no sentido de formar estas comunidades, e para as estórias de Rosa e Vieira, estas forças podem ser traduzidas nas modificações e motivações que se tornaram imperativas em decorrência tanto do passado colonial, como da

16 Tal datação, em nota do próprio autor se dá a partir de considerações do momento em que o termo nacionalismo generaliza-se. 
necessidade de afirmação das identidades que mencionamos anteriormente, as quais, por sua vez, representam o esforço de construção de uma narrativa onde seja considerado o desejo de autonomia nacional frente às fontes "externas":

O que estou propondo é o entendimento do nacionalismo alinhado-o não a ideologias políticas conscientemente adotadas, mas aos grandes sistemas culturais que os precederam, e a partir dos quais ele surgiu, inclusive para combatê-los. (ANDERSON, 2008, p. 39)

Trazer esta argumentação de Anderson neste momento cumpre o papel de nela poder sublinhar a possibilidade de compreensão das imagens identitárias nacionais nas obras, muitas vezes, como uma via de contestação dos próprios sistemas culturais que as engendram.

Sendo assim, a imaginação nacional que se gesta nos países que passaram pela experiência de serem colônias europeias, apesar de transplantar a modulação nacional de que nos fala Anderson, o fazem, também, para desvincularem-se da grande nação construída na vontade de duplicação e ampliação do modelo da metrópole que o colonialismo Ihes impunha. Voltando aos textos literários, as considerações de Rita Chaves para o contexto angolano, mesmo contrapondo-o ao brasileiro, em momento diferente daquele que observamos neste trabalho, não deixam de ser bastante interessantes para corroborar ao que vimos procurando explanar:

Cumpre ressaltar que, sofrendo o impulso da modernidade, a formação do nacionalismo no projeto literário angolano exprime a opção por um sentimento nativista que, na base, difere daquele que subjaz, por exemplo, às nossas obras românticas, produzidas na fase em que nossos escritores mostravam-se mais enfaticamente preocupados com a idéia de fundar a nacionalidade brasileira. $O$ apreço pelo localismo como força moduladora se imprime dinamicamente, apoiando-se não nos rincões distantes dos efeitos da colonização, mas no burburinho dos lugares, onde marcar do 
estrangeiro somam-se aos chamados valores de raiz (CHAVES, 2002, p. 25)

O impulso nacionalista aparece, pensando o contexto em que surgem as literaturas angolanas, que é o das lutas de libertação, aliado ao papel de trazer à tona a singularidade que subjaz nos projetos totalizantes, os quais na tentativa de homogenização dos povos subjugados, acaba por tomá-los como massa indistinta pronta a ser padronizada pela missão civilizadora.

Deste modo, trata-se de uma empreitada artística que ao revelar as fissuras da situação colonial, observadas, sobretudo, pela limitação da penetração da referida missão civilizadora, acaba por revelar, em igual medida, para nos utilizarmos de uma expressão de Balandier (1993), o caráter de "inautenticidade" da situação colonial.

Dessa maneira, a nação passa a ser imaginada pela literatura como espécie de movimento desconstitutivo da dependência metropolitana, como observamos em Frank Marcon:

As retóricas sobre a nação passam pela argumentação de uma estética nacional. A própria literatura é também narrada e enfatizada por noções de originalidade, singularidade e especificidade não só temáticas como estilísticas e linguísticas. Além de narrar a nação, as literaturas também são narradas como significantes nacionais quando se tornam símbolos de uma identidade para alguns. Há aí um movimento duplo em que ao narrar a nação na literatura (...) se está inventando a própria ideia de uma literatura da nação. (MARCON, 2005, p. 36)

Noções como a invenção, a singularidade e a identidade passam tanto pela argumentação de Marcon, como pela nossa própria, e como tal, já foram pontuadas em outros momentos deste trabalho. Por ora, para a continuidade aqui proposta, 
sobressai-se uma outra ideia bastante cara, a de que essa imaginação nacional poderá surgir no texto não apenas tematicamente, mas a partir de procedimentos estilísticos e linguísticos, fato que ocorre nas narrativas analisadas, as quais, embora não tragam a identidade nacional, explicitamente, como tema, refletem as especificidades de seus países ao levarem a efeito uma construção estética inovadora e de rupturas.

Vale lembrar que o direcionamento ao que é específico não é encarado como uma essencialização mas, na verdade, como a mobilização de forças conflitantes que passarão a significar pelo como como são apreendidas:

Logo, a questão da identidade nacional será encarada como um dos pólos de um processo dialético, portanto, como meio indispensável para entrar em relação com o outro, e não como um fim em si mesmo. A busca da identidade deve ser vista como processo, em permanente deslocamento, como travessia, como uma formação descontínua que se constrói a partir de sucessivos processos de territorialização e desrretorialização. (BERND, 1992, p. 10)

Desta forma, inscrita num processo dialético, uma abordagem da identidade nacional pensada a partir de narrativas literárias passa, necessariamente, por observar como se darão estas relações com o outro, em nosso caso, observar como o passado colonial no caso brasileiro, e a presença colonial, no angolano, se modulam com outras presenças no intento de retraçar não só a literatura, mas uma visão de seus povos, almejando, assim, uma autonomia que lhe possa arrancar a uma localização e uma definição periférica.

Isto posto, para efeitos de organização e melhor explanação do que apontamos até aqui, a sequência do capítulo se fará a partir da observação dos seguintes aspectos: a organização do pensamento e discurso colonial, sobretudo o 
português, nos pontos que podem ser comuns ao Brasil e a Angola, partindo para as ideias de sobre a infância e de como a criança pode ser escrita como metáfora desse empenho nacionalista, confluindo a juventude da personagem com a juventude da nação e, por fim, chegando às distinções desse processo em Rosa e Vieira, o primeiro assumindo para sua literatura a missão de harmonização dessas forças conflitantes e o segundo deixando entrever uma tensão, pela emergência da violência, a partir da constatação da impossibilidade da assimilação.

\subsection{O discurso colonial português: entre a harmonização e a impossibilidade de assimilação}

Como vimos tentando demonstrar até o momento, a inscrição da singularidade nos textos de Luandino Vieira e Guimarães Rosa associa-se, de modos distintos, à evidenciação pela narrativa também de uma imagem contrária àquela forjada e construída em seu passado/presente colonial. E como constante intencional dessa operação estaria, como já afirmamos, o impulso nacionalista, um dado até certo ponto comum na formação dos sistemas literários de países como Brasil e Angola.

Desse modo, ao alinharem-se a uma redefinição identitária, tomando o que Ihes é "próprio" e as modificações vindas de fora, estes textos guardam relação com o que Stuart Hall define como a dinâmica da identificação na pós-colonialidade "O 'Outro' deixou de ser um termo fixo no espaço e no tempo externo ao sistema de identificação e se tornou uma 'exterioridade constitutiva' simbolicamente marcada" (HALL, 2003, p. 109) 
Sendo assim, também intentamos, aqui, observar este "outro" que foi o domínio colonial a partir da afirmação de seu próprio discurso, e de igual maneira avaliando qual foi a amplitude exercida pelo seu domínio, para enfim, chegar às respostas que os escritores fornecem a este discurso, seguindo, em alguma medida, caminho similar ao proposto por Vima Lia Martin no estudo de personagens marginalizadas em perspectiva comparada entre o autor brasileiro João Antônio e José Luandino Vieira:

Sobre a brutalidade dos primeiros embates entre o povo colonizador e os povos colonizados foram-se estabelecendo várias estratégias políticas para garantir a primazia econômica de Portugal - e de outros países mais desenvolvidos de que ele também dependia sobre os territórios ocupados.

Essa realidade secular certamente que adquiriu contornos próprios em cada uma das ex-colônias, mas é um legado comum que se traduz, em parcela significativa da produção literária desses países, na construção de obras ficcionais representativas dos problemas cotidianos enfrentados pelas populações socialmente marginalizadas, parte deles decorrentes da sistemática da colonização.(MARTIN, 2006, p. 183)

Considerar a situação colonial para os propósitos desta leitura, mesmo assumindo os riscos decorrentes das narrativas situarem-se em contextos históricos distintos, se dá em fato de que ela - a situação colonial - atualiza-se no que é comum às obras: uma expressão de autonomia. Isto ocorre mais efetivamente em Angola, por tratar de uma "presença" a ser combatida, mas também nos impasses da modernidade brasileira, quando as identidades são refletidas em consonância com uma caracterização que encontra ecos na presença portuguesa no país.

Tal reflexão é levantada, por exemplo, nas considerações de Paula Monteiro, quando revisita a situação colonial para introduzir uma nova edição e tradução do texto de Balandier, "A situação colonial”, do qual inclusive nos valemos aqui, e 
procura justificar a atualidade no texto, apontando que o lastro colonial que aparece na contemporaneidade brasileira não se trata de uma presença direta como aquela combatida no contexto das independências africanas, entretanto pode ser relevante para pensar as relações étnico-raciais, nas discussões sobre exclusão e miscigenação, ou seja, nas reflexões sobre a identidade, e desta maneira nos apresentaria problemas bastante similares àqueles que o colonialismo impusera às culturas africanas.

Neste sentido, cumpre-nos refletir sobre a gênese destas relações étnicoraciais na própria configuração do colonialismo, que seja o de fundar-se na expropriação e de, a partir de um olhar eurocêntrico que lhe é fundador, considerar as diferentes etnias com base em categorizações inferiorizantes, procurando, como desdobramento, desembocar nas forças de harmonização ou exacerbação de conflitos.

Para o caso português a vinculação entre a colonização e uma inferiorização dos não-europeus se afirma com a potencialidade de sua empresa escravista. Como bem explica Alencastro (2000), ao denominar Lisboa, capital portuguesa, como a capital negreira do ocidente, ressaltando um certo "protagonismo" lusitano durante o século XVI na comercialização de negros africanos escravizados. No período, também observou que com o aumento gradativo da lucratividade e da intensidade deste comércio, o número de africanos deportados para as Américas toma expressivas cifras e, assim, "o comércio negreiro deixa de ser uma entre várias atividades ultramarinas iniciadas com os Descobrimentos e converte-se no principal esteio da economia do império do Ocidente" (ALENCASTRO, 2000, p. 78), comercialização que em sua gênese traz a inferiorização destes africanos. 
Valentim Alexandre, irá observar que esta ideia de protagonismo português associada à inferiorização do africano penetra indelevelmente o pensamento racial português. Para o historiador português, os debates em torno da abolição do tráfico negreiro, com a resistência portuguesa a tal procedimento, mesmo após a proibição em 1836, são exemplares da visão da escravização como uma missão a cumprir, por "vocação" do português, de um lado, e por uma irremediável inferioridade africana, de outro:

Para a ideologia dominante [...] a raça negra estava irremediavelmente ferida por uma inferioridade inata: tratar-se-ia de uma 'população selvagem', 'essencialmente indolente', inclinada por natureza à embriaguez e ao roubo, que não conhecia nenhum dever social nem experimentava 'sentimento do amor à família ou o do amor do próximo'. Desta concepção se partia para a justificação do tráfico de escravos [...], como também da escravatura, única forma de, pela obrigação do trabalho, dar umas tintas de civilização a quem, por outro modo, Ihe seria forçosamente alheio (ALEXANDRE, 1999, p.135).

Logo, manifesta-se uma das características centrais do colonialismo, e da qual, mesmo em temporalidades distintas notamos a presença como preocupação, evidente ou não, da intelectualidade da qual fazem parte Rosa e Vieira, e que nomeadamente, trataria-se da colonização, como enfatiza Memmi, trazer em si a criação de um mundo superior, do qual faz parte o colonizado, e do qual ele desejará, sob a falácia de imprimir civilidade aos que estejam fora dele, não extrair outra coisa, senão, privilégios.

Nesta avaliação de Valentim Alexandre sobre a maneira como as diferenças étnicas ocupam o colonialismo português, é factível partir para uma outra questão, o seu caráter assimilacionista como capaz de imprimir uma diferença vocacional dos portugueses em relação a outros colonizadores, que encontrará, talvez, a sua mais 
conhecida análise em Gilberto Freyre, com a proposição do luso-tropicalismo.

Dadas as limitações desta abordagem, não pretendemos aqui um aprofundamento da obra de Freyre, ainda assim, nos cabe algumas considerações sobre o caráter de miscibilidade de vocação lusitana que o autor imprime ao trato português com suas colônias. Para tal, nos valeremos da leitura feita pela historiadora Maria da Conceição Neto, em "O luso, o trópico... e os outros”, na qual há um questionamento tanto da perpetração dessa miscibilidade, quanto da existência de um trópico e, indo mais além, de um luso:

Que não houve, historicamente falando, "um Trópico", mas sim diversas civilizações nas áreas tropicais, julgo que já nem se discute. Mas também "o Luso" não existiu (nem "o Gaulês" nem "o Anglosaxônico"), há história do avanço da frente atlântica para o interior da África: existiram grupos e pessoas, por vezes instituições, que agiram de modo diverso ou mesmo contraditório, condicionados pelas culturas do seu tempo e pelos interesses que defendiam. (NETO, 1996, p. 117)

A autora rompe, desse modo, com a ideia de uma unidade no comportamento e nos ideais portugueses de colonização, citando, por exemplo, que mesmo os propósitos de assimilação eram vistos de maneiras distintas entre a população lusitana, sendo para alguns, nociva e prejudicial a Portugal, visão manifesta através das leis que limitavam e restringiam a possibilidade de assimilação, ou possível para outros, mas não no intuito de integração, e sim como a justificativa da missão civilizadora, como imperativo de "domesticar" os bárbaros para que estes pudessem servir plenamente aos propósitos de expansão do império português.

É certo, que a investigação de Freyre inaugura um pensamento que reorienta as interpretações de natureza degenerativa e puramente biológica sobre a miscigenação, e mesmo não negando completamente o conceito de raça, avança no 
sentido de observar o fenômeno a partir de uma perspectiva cultural e deste modo, podendo incluir, com vivacidade descritiva, a contribuição do africano na formação do caráter brasileiro.

No entanto, do ponto de vista do contato entre as etnias, forjado no contexto da colonização, o intento de harmonização de forças conflitantes percebido nos textos do autor, principalmente em Casa Grande \& Senzala, acaba por possibilitar uma leitura que minimiza a evidenciação da violência destes contatos, na medida em que o colonizador português retratado na obra do autor, em muitos momentos de sua narrativa, demonstra uma espécie de disposição a estas trocas culturais, como podemos observar na parte final do levantamento feito por Freyre das características da peculiaridade brasileira, em consonância com o caráter da colonização portuguesa:

Considerada de modo geral, a formação brasileira tem sido, na verdade, como já salientamos às primeiras páginas deste ensaio, um processo de equilíbrio de antagonismos. [...] É verdade que agindo sempre, entre tantos antagonismos contundentes, amortecendoIhes o choque ou harmonizando-os, condições de confraternização e de mobilidade social peculiares ao Brasil (...). (FREYRE, 2001, p. 125)

Se o sentido de harmonização, mesmo que questionado em diferentes perspectivas teóricas em diferentes períodos históricos, encontra o espaço para ampliar-se em território brasileiro, pois as relações entre colônia e metrópole, neste caso, ganham contornos bastante singulares, para o contexto angolano, a ideia do assimilacionismo colonial português não encontra terreno para desenvolver-se:

Quanto à "assimilação" ou "integração" que alguns querem como apanágio constante da política portuguesa em África, seja para Ihe elogiarem a relativa "harmonia racial" ou para a acusarem de ter forçado a "portugalização" e destruição das identidades culturais africanas, essa ideia não resiste ao confronto com os factos, quer 
analisemos os textos jurídicos, os discursos dos políticos ou a realidade social concreta. Repetirei aqui, mais uma vez, que o estereótipo da colonização portuguesa "assimiladora", "não-racial", caracterizada pela mestiçagem, é falso no que diz respeito à fase da efectiva ocupação da maior parte do território de Angola. A legislação era segregacionista, o poder preocupava-se mais em excluir do que integrar (...). (NETO, 1996, p. 119)

A assimilação mostra-se, portanto contraditória e inviável em sua própria estrutura, pois observando mais atentamente a legislação segregacionista destacada por Neto, percebe-se que mesmo em seu intento civilizador, este é um projeto de desumanização do colonizado, que lhe destituindo qualquer traço positivado, termina por intentar não uma integração, e sim uma remodelagem com vias a potencializar a extração de vantagens e obtenção de lucros na colônia.

Dessa forma, os projetos assimilacionistas para as províncias ultra-marinas (denominação das colônias nesta conjuntura) no início do século $X X$, período da efetiva ocupação do território africano como o define a autora, tem como pano de fundo uma intenção tutelar, no pior sentido do termo, e modeladora, desde as Leis Orgânicas de administração civil e financeira das províncias ultramarinas em 1914, as quais consideravam o governador da colônia "protetor nato dos indígenas" até a Carta Orgânica de Angola (1917) onde foi gestado o código de indigenato ${ }^{17}$ que previa as seguintes obrigações para o indígena que pretendesse o status de cidadão assimilado, condição que lhe permitiria gozar, assim, dos mesmos direitos civis e políticos dos cidadãos portugueses: $1^{\circ}$ - saber ler e escrever a língua portuguesa; $2^{\circ}$ - possuir os meios necessários à sua subsistência e a das suas famílias; $3^{\circ}$ - ter bom comportamento, atestado pela autoridade administrativa da área em que

17 Eram considerados indígenas todos aqueles da raça negra ou seus descendentes que por ilustração e costumes não se distinguiam do "comum" àquela raça. 
reside; $4^{\circ}$ - diferenciar-se pelos usos e costumes do usual da sua raça.

Esta breve exposição da mencionada legislação põe em cena que no fim das contas a assimilação, se é que ela realmente poderia efetivar-se, longe de ser agregadora, levava a uma extrema segregação e à subjugação do colonizado. Retomando a inviabilidade de tal projeto, ela faria-se, por um lado, pela dificuldade do colonizado em atender a todas estas exigências, dadas as efetivas condições políticas, econômicas e sociais, e por outro, porque aderir ao código de assimilação significaria romper-se a si próprio, tarefa que além de violenta, parece-nos igualmente impossível.

Por fim, a adesão à assimilação significaria, também, aceitar a construção, advinda do colonizador, mítica, carregada de estereótipos e racista de sua própria imagem, ou seja, recorrendo a Memmi, seria um preço demasiado exorbitante a ser pago, e na falta de condições e vontade para tal pagamento residiria a impossibilidade de concretização.

\subsection{Dos modos de pensar a infância}

A origem latina da palavra infância está guardada em infantia, cujo significado é a incapacidade de falar, contudo, tanto nas narrativas analisadas como nas reorientações do pensamento sobre a criança, a gênese do conceito perde efeito, isto é, a criança longe de significar ausência de fala, de palavra, é sujeito ativo na criação de linguagens, formando seu próprio mundo e participando de outros ou como afirmou Benjamin, formando "um pequeno mundo inserido no grande" 
(BENJAMIN, 2002, p.104).

Com base na vertente que coloca a infância como espaço privilegiado para a imaginação criativa é que procuramos seguir a leitura das personagens infantis nas estórias brasileiras e angolanas, tomando a criança não apenas como tema, mas intricada à estrutura das estórias, de modo a oferecer-lhes os contornos da inventividade poética, bem como refletir concepções de estética, identidade e imaginação nacional.

Neste sentido, observamos com atenção o percurso crítico de Vânia Maria Resende em seu estudo sobre o menino na literatura brasileira, para quem a presença da personagem infantil na moderna ficção brasileira poderia despertar uma atitude instigante no leitor dessa literatura que o levaria a:

(...)constatar, na maioria deles [textos ficcionais], significados humanos e estéticos profundos, emergentes de um mundo metafórico, em que se cruzam símbolos da imaginação criadora e imagens da realidade infantil - fonte mágica, vivificante, de que o criador pode tirar grandes efeitos, realizando, de forma plena, a ficção de sua escritura. (RESENDE, 1988, p. 23)

Entre os efeitos de sentido que podem ser retirados deste universo, para além daqueles relacionados à atmosfera mítica da infância, acrescentaríamos as intersecções com uma realidade social observada, lembrada, criada, vivida e idealizada pelos escritores e poderíamos, então, associar esta outra dimensão à imaginação nacional, seja num sentido de evidenciar um desejo de harmonização presente no ponto de vista manifesto explícita e implicitamente no texto, como o faz Rosa, seja para evidenciar, com igual jogo de explicitação e camuflagem, as fissuras e a violência que obrigatoriamente tornam esta imaginação dialética e tensa, o que 
ocorre em Luandino Vieira.

No que tange à produção intelectual, do pensamento social à literatura, a infância sempre ocupou algum espaço, embora isto não seja tão efetivamente discutido. Para nos limitarmos ao alcance teórico deste trabalho, o próprio Gilberto Freyre, a quem recorremos para discutir os intentos assimilativos da empresa colonial portuguesa, poderá nos servir para ratificar esta presença da infância, dada o fato de em sua obra não serem poucas as referências da imagem da criança para pensar a configuração social, política e econômica da sociedade brasileira.

Embora no trato com a infância Freyre seja mais contundente ao evidenciar a violência surgida através das zonas de contato $^{18}$ através de um minucioso levantamento da dinâmica do universo infantil indígena, africano e português, da mesma forma, como a orientação geral da obra, as diferenças e a violência são apresentadas de maneira a apontar para uma leitura bastante peculiar, no sentido dos lugares e papéis estarem muito bem limitados dentro deste painel, mostrando assimetrias e hierarquias inquestionáveis que, todavia, são organizadas coesamente de modo a "amortece-lhes o choque", para utilizarmos de expressão do próprio autor, como por exemplo, em sua conclusão sobre o contato entre indígenas e europeus:

Se na utilização, aproveitamento ou adaptação de todo esse material de cultura indígena entrou, na maior parte das vezes, a inteligência ou a técnica do europeu como função quase criadora, ou pelo menos transmutadora, noutros casos o que se deu foi a pura transmissão dos valores ou conhecimentos de uma cultura à outra - da nativa à adventícia. (FREYRE, 2001, pp. 196-197)

18 Zonas de contato é um conceito cunhado por Mary Louise Pratt e se refere aos "espaços sociais onde culturas díspares se encontram, se chocam, se entrelaçam uma com a outra, freqüentemente em relações extremamente assimétricas de dominação e subordinação". (PRATT, 1999, p. 27) 
Freyre equaciona uma natureza criadora do europeu com uma cultura nativista do indígena prontas para serem mutuamente transmutadas como se suas assimetrias pudessem harmonizar-se sem barreiras dum ou doutro lado, por vocação e instinto.

Ainda assim, mesmo suscitando uma série de estereótipos, cumpre destacar que em sua argumentação, o autor colocará a criança, o menino, como denomina, na centralidade para se pensar como se estabelecem as trocas culturais numa situação colonial, ou seja, através do 'menino' cria-se o veículo civilizador das missões junto aos autóctones, pois este seria a via pela qual chegaria, às casasgrandes, significativa parte da cultura indígena.

Claro está que não pretendemos esgotar toda a construção da infância em Freyre, isso por si só seria tarefa para uma série de outros trabalhos de investigação, mas acreditamos já ser possível destacar que mesmo na ambiguidade de pensamento freyriano, a criança será importante para a imaginação nacional, bem como, neste esforço de harmonização, a imagem da mesma pode acabar por tornar-se metáfora da convivência, onde é amenizado o impacto da violência.

Partindo ao contexto angolano outras questões podem contrapor-se a este apelo agregador no trato da infância. No caso de nos atermos às crianças que povoam a obra de Luandino Vieira temos condições de visualizar o percurso de construção da imagem da criança desde a tomada de consciência até o imperativo da necessidade de luta.

Diante de um mundo compartimentado, cindido em dois (FANON) a situação da criança durante a colonização não poderá ser menos conflituosa, Memmi nos 
atesta que tomando como base o processo de mutilação social e histórica da colonização, pouca, ou nenhuma, será a esperança do colonizado que possa projetar a cidadania de suas crianças, há uma interdição desta cidadania na perspectiva pedagógica, para nos concentrarmos em apenas um dos domínios, cuja formalização, na instituição educacional formal, privilegiará sempre a perspectiva da nação colonizadora.

Contudo, a partir dos impulsos utópicos que se sobressaem nos anseios de libertação, passa-se a projetar nas crianças a perspectiva da novidade e da liberdade: "as crianças passam a representar emblematicamente na narrativa o novo, o futuro em que os próprios angolanos resolverão suas contendas, no espaço que lhes é próprio e que eles não poderiam ser derrotados" (MACÊDO, 2008, p. 147), acrescentando, ainda, que as personagens infantis tornam-se constantes no período das lutas de libertação.

O espaço a que chama atenção a autora é o dos musseques, que ao mesmo tempo em que permite a emergência das vozes silenciadas pelo colonialismo, é também o espaço onde se agudiza a violenta face colonial já perpetrada aos gestos dos colonizados. Esta violência traz junto consigo a evidenciação das contendas, das makas para usar uma expressão propícia ao contexto, e surge deste modo uma outra senda para a leitura das crianças: entre rupturas, tensões e projeções estarão elas simbolizando a complicada tarefa de imaginar identidades que se inscreverão na nação livre, quadro em que se encaixariam as personagens infantis de No antigamente, na vida. 


\subsection{Dos modos de pensar/lidar a violência}

O percurso de compreender o discurso colonial, frisando, novamente, como presença direta ou remanescências constituintes, cumpre agora o seu papel na continuidade da leitura, que seja o de situar a violência no contexto de elaboração dos contos de Guimarães Rosa e Luandino Vieira.

Comecemos, pois, pela evidenciação, e assim, cabe-nos uma revisitação da violência no texto de Fanon, Os condenados da Terra, no qual a noção de fragmentação, a qual já recorremos durante este trabalho, é essencial na compreensão do mundo colonial. Ora, num contexto em que a diferenciação é a tônica e, por sua vez, definirá as realidades econômicas, sociais e culturais dos indivíduos, a violência tem centralidade, definindo e movimentando esta situação:

A violência que presidiu ao arranjo do mundo colonial, que ritmou incansavelmente a destruição das formas sociais indígenas, demoliu sem restrições os sistemas de referências da economia, os modos de aparência, de indumentária, será reivindicada e assumida pelo colonizado no momento em que decidindo ser a história em atos, a massa colonial irromperá nas cidades proibidas. (FANON, 2005, p. 57)

No entanto, destacamos o trecho na argumentação de Fanon menos para evidenciar que a violência define a situação colonial, e mais para pensar a resposta do colonizado nos momentos de libertação.

Fanon afirma que tal violência é reivindicada e assumida pelo colonizado a partir do momento que este decide tomar os rumos de sua história, desta forma, esta violência manifestar-se-á tanto em sua face brutal, com a luta armada, mas também se manifestará de uma outra forma central à leitura que nos propusemos: apreendida pelo sujeito colonizado e subjugado na própria estrutura das narrativas 
que a reivindicarão como espaço para a reelaboração de histórias e identidades.

Voltando-nos ao campo da literatura, é pertinente trazer à cena o processo de elaboração de No antigamente, na vida. O livro, assim como boa parte da obra ficcional de Luandino Vieira, foi escrito durante os anos que esteve no campo de concentração do Tarrafal, em Cabo Verde, cumprindo pena por atividades subversivas contra a segurança do Estado, decorrentes de seu envolvimento com as lutas de libertação nacional e de participação no MPLA, entre os anos de 1961 e 1972, e segundo declarações do autor em entrevista a Debora Leite David, No antigamente, na vida, foi escrito nos anos mais duros de prisão, em que estava submetido a mais privações, e que isto reflete-se num livro igualmente duro.

Observar, pois, a exacerbação da violência em No antigamente, na vida, significa mirá-la como o filtro pelo qual o autor passa a construção de sua narrativa e de suas personagens. Desta forma, a escrita cumpre também um papel de denúncia, daquela violência que de antecedente torna-se definidora, na medida em que evidencia a violência não somente sendo exercida sobre o colonizado, mas passando a definir suas ações e personalidades, buscando nesta operação uma auto-afirmação, no caminho postulado por Memmi: "Mas desde logo, a reivindicação colonizada adota esta figura diferencial e concentrada sobre si mesma: é estritamente delimitada, condicionada pela situação colonial e pelas exigências do colonizador" (MEMMI, 1977, p. 114).

Congregando os pensamentos de Fanon e Memmi, saímos com a noção da impossibilidade de uma separação entre os colonizados, subjugados, e a matéria que os subjuga, no caso de nossa leitura, a violência. 
Do contexto das lutas de libertação de Angola e da violência pensada por Fanon como gesto revolucionário, seguimos para o brasileiro, com os impasses da modernização que situam o momento de produção das obras de Guimarães Rosa. E neste autor, perceberemos respostas bastante diferentes daquelas que encontramos em Luandino Vieira.

Quando vimos situando a caracterização do universo das crianças de Rosa em confluência com um intento harmonizador não pretendíamos com isto, ignorar que a obra, de alguma maneira, também tratará de personagens despojados, aislados e subjugados, tanto que no livro, mesmo nos contos sobre os quais nos detivemos abunda a presença de velhos, loucos ou personagens que estejam descentradas.

No entanto, o modo de apreensão e a ambientação da vivência destas personagens consegue afastar a face mais brutal da violência, como está evidenciado em Luandino.

O crítico Ettore Finazzi-Agró, para nos determos em uma leitura espefícica, que procurou estudar a violência e a marginalidade em Guimarães Rosa, faz uma análise romance Grande Sertão: Veredas apreendendo um movimento que segundo ele que passaria da "violência brutal para um estado de harmonia" (FINAZZI-AGRÓ, 1998, p. 83).

Segundo sua leitura, tal operação se dá numa transferência do alvo real da violência para um alvo que seja simbólico e capaz de minimizar os impactos, o crítico ainda cita para corroborar à sua argumentação, um trecho do romance em que Riobaldo não encontrando motivos para matar um homem que se encontrava 
diante de si e tendo dentro de si um impulso para cometer um ato violento, promete aos presentes, que irá matar o primeiro que Ihe apareça na frente. Contudo, surge um homem e Riobaldo sente pena dele, ao que decide, então, matar uma cadela, dizendo tê-la visto primeiro; o jagunço também não mata a cadela e transfere o intento de matar para a égua em que estava montado o homem; no fim, não mata nenhum dos três, e de transferência em transferência, termina afirmando que égua não era gente e que não se podia matar.

Para o crítico todas estas transferências passam a violência de um estado brutal para um simbólico e, indo mais além, até nulo - operação que apreendemos também, com diferenciações, nos contos de Primeiras Estórias.

Acreditamos, inclusive, que no plano da estruturação narrativa isto acontece não apenas nos contos que analisamos, nos quais as transferências e a obnubilação da violência, em muito, estariam encerradas numa leitura que privilegia a atmosfera onírica e mágica das narrativas, mas aparecem em outros momentos, nos quais evidencia-se a orientação harmonizadora de seu projeto estético. Este é o caso de "Famigerado", por exemplo, em que a ameaça de morte diante do jagunço que precisa saber o sentido da palavra famigerado, podendo dissolver o narrador, doutor-letrado, "com um pingo no l", não se cumpre graças a uma transferência de poder que é conferido ao narrador pela capacidade de explorar os sentidos da palavra e, ironicamente, deixar a violência de seu interlocutor em suspenso.

Diante do exposto, esperamos ter explicitado os problemas que as narrativas nos colocaram e, passamos agora para uma focalização nos textos, especificamente, para dar a entender quais foram os pontos nos textos que nos permitiram realizar tais formulações. 


\section{3- A palavra singular: do triunfo da alegria à emergência da violência}

\subsection{Da "Partida do Audaz Navegante" às aventuras do 'aldaz' navegante: suplantando as faltas no devir da fantasia}

Dentre as estórias protagonizadas por um narrador infantil, "Partida do Audaz Navegante" apresenta uma estrutura bastante intrigante para refletirmos sobre a dissolução das faltas, ou por outra, do sentido "harmonizador" que apontamos para os textos de Rosa no primeiro nível de análise, o das reinvenções enquanto baliza do projeto estético do autor.

Concorrem no conto duas narrativas: a estória de Brejeirinha, suas irmãs, Ciganinha e Pele, e Zito, o de fora, "só primo", trazida ao leitor por um narrador onisciente, e a estória contada por Brejeirinha, que dada a formar "muitas artes", aproveita o experienciado com as outras crianças para inventar a sua própria fábula, ou seja, congrega universos, em princípio, muito diferentes, com seu enigma inicial: "'Eu sei por que é que o ovo se parece com um espeto!" -; ela vivia em álgebra. Mas não ia contar a ninguém." (p. 167) ${ }^{19}$

19 Sobre os sentidos de harmonização de contrários que sugere a fala inicial de Brejeirinha vale observar as considerações do próprio Guimarães Rosa em carta a seu tradutor alemão Curt Meyer-Clason de 24 de março de 1966 tratando das expressões que este último teve dificuldade de encontrar um sentido em alemão para a traudução do conto em questão, as quais passamos a citar: "'espeto' = literal, literalíssimo. Há, em português, a expressão: 'Tão parecidos como um ovo e um espeto', para dizer que duas coisas, ou duas pessoas, são muito diferentes uma da outra. Aqui, Brejeirinha descobre uma profunda verdade metafísica, desmoralizadora da nossa concepção idiota da "realidade estática": as coisas aparentemente diferentes, são em verdade, às vezes, as mais próximas uma da outra. Veja, a respeito, o próprio título, e o próprio tema da estória." (ROSA e MEYER-CLASON, 2003, p. 316) 
Em outras palavras, estamos diante da estória dentro da estória, e esta segunda narrativa será contada/criada por Brejeirinha num dia chuvoso em que parte para brincar com as irmãs e o primo, estória esta em que irá ficcionalizar o tema do amor e da partida, a partir da relação afetiva que observa entre o primo, Zito, e a irmã, Ciganinha.

Na estória primeira, depreende-se que o primo está em visita e deve/deseja partir em breve e que, além disso, decorrente de ciúmes "sem motivo de quê nem de quem" (p.167), encontra-se brigado com Ciganinha. Ao passo que, a partir da voz de Brejeirinha, a qual percebe tanto o estado enamorado de ambos, como a tensão pela briga, a expectativa da partida do primo torna-se a estória da partida do 'aldaz' navegante partindo para descobrir "os outros lugares valetudinário", "os lugares que nós não vamos nunca descobrir" e deixando, atrás de si, a moça:

"Sem saber o amor a gente pode ler os romances grandes?" -
Brejeirinha especulava - "É, hem? Você não sabe ler nem o
catecismo" Pele lambava-lhe um tico de desdém; mas Pele não
perdia de boazinha e beliscava em doce, sorria sempre na voz.
Brejeirinha rébica, picuíca - "Engraçada!... Pois eu li as 35 palavras
no rótulo da caixa de fósforos". Por isso, queria avançar afirmações,
com superior modo e calor de expressão deduzidos de babinhas. -
"Zito, tubarão é desvairado, ou é explícito ou demagogo?" Porque
gostava, poetista, de importar desses sérios nomes que lampejam
longo clarão no escuro de nossa ignorância. Zito não respondia,
desesperado de repente, controversioso-culposo, sonhava ir-se
embora, teatral, debaixo de chuva que chuva, ele estalava numa
raiva. Mas Brejeirinha tinha o dom de apreender tenuidades: delas
apropriava-se e refleti-as em si - a coisa das coisas e a pessoa das
pessoas - "Zito, você podia ser o pirata inglório marujo, num navio
muito intacto, para longe, lo-õ-onge no mar, navegante que o nunca-
mais, de todos?" Zito sorri, feito um ar forte. (ROSA, 2001, p.168)

Assim começa a estória do "aldaz" navegante, com o sedutor convite que a "poetista" faz a Zito para participar da estória e compactuar com a nova versão que fará dos fatos, e o garoto, inicialmente fechado, pensando em sua partida, acaba por 
aderir, num sorriso, à proposta de Brejeirinha.

Decerto, há ainda nesta passagem considerações importantes do narrador, descortinando algumas proposições sobre a escrita que caminham no sentido de que no ato ficcional há um certo dom de apreender tenuidades, sabendo apropriarse e refleti-las em si, operando a singularização necessária para a construção da linguagem literária: coisas passam a ser a coisa, pessoas passam a ser pessoa, ou seja, tornam-se expressões significativas para as representações a que se propõe o texto.

De volta à continuidade dos enredos, restam ainda Ciganinha e Pele embarcarem na fabulação da irmã, e a primeira mostra-se a mais resistente, fazendo, a todo tempo, ressalvas e procurando instaurar um senso de "realidade" ao enredo de Brejeirinha: "Você é uma analfabetinha aldaz!" (p. 169); "Sim. E agora? E daí?" (p. 172); "Na-ão. Não vale! Não pode inventar personagem novo no fim da estória, fu!" (p.173); a segunda fecha-se em zangas, em silêncios e, sobretudo, na preocupação com a partida do primo.

Contudo, a ambas Brejeirinha convence com sua insistência de "antes falar bobagens, que calar besteiras", com o "não detendo em si o jacto de contar", até que a metáfora ganha contornos palpáveis no estrume que aparece entre as correntezas ao cessar da chuva, para o qual, Pele aponta dizendo ser o 'audaz navegante'.

Inicialmente, Brejeirinha faz careta à proposição da irmã, não aceitando este elemento concreto e sem beleza em sua narrativa, mas cede e acaba o enfeitando de flores, ramos e gravetos e "Pronto. É o Aldaz Navegante..." e "Já aquela matéria, o 'bovino', se transformava". (p.173) 
Cumpre destacar que pouco antes do acontecido Brejeirinha havia suspendido sua estória, o "Aldaz Navegante" partira ao mar e desaparecera. No entanto, diante do novo fato - o surgimento do "bovino" - e de notar a tristeza de Ciganinha e Zito, que percebiam na fábula reflexo de sua experiência, a garota retoma a estória com a anuência de todos, inclusive do narrador ${ }^{20}$ :

E a estória? Haverá, ainda, tempo para recontar a verdadeira estória? Pois. "Agora, eu sei. O Aldaz Navegante não foi sozinho, pronto! Mas ele embarcou com a moça que ele amavam-se, entraram no navio, estricto. E pronto. O mar foi indo com eles, estético. Eles iam sem sozinhos, no navio, que ficando cada vez mais bonito, mais bonito, o navio... pronto: e virou vagalumes..." (ROSA, 2001, p. 174) ${ }^{21}$

Pronto, também no conto primeira fecha-se a estória primeira, a do narrador, com um trovão e a mãe que vindo buscar as crianças, preocupada, sobretudo, com Brejeirinha, que temia muito os trovões. Aqui os níveis narrativos sobrepõem-se, Ciganinha e Zito haviam reconciliado-se pouco antes com a promessa do primo de voltar "muitas vezes", e o aldaz navegante já não parte sozinho, mas junto com a moça, seguindo os dois "sem sozinhos".

A ausência e a iminência da partida que pareciam ser a tensão de ambas a estórias, dissolvem-se num desejo de reversão, de mudança dos rumos das estórias, que se materializa numa solução apaziguadora, decorrente de mistério e vontade.

20 O narrador, aliás, dá outras mostras desta anuência e cumplicidade com a estória narrada por Brejeirinha o que pode ser notado, por exemplo, nos momentos em que o autor se inclui no relato com a utilização da expressão "a gente": "e a gente ficava quase presos" (p. 166), ou ainda, "Se a gente se virava, via-se a casa, branquinha com a lista verde azul” (p.170)

21 Os vocábulos em negrito são grifo nosso, já o trecho em itálico é grifo do autor, utilizado, aliás, durante toda a narrativa para marcar tanto os trechos em que é contada a estória de Brejeirinha, como aqueles em que aparecem as falas das outras personagens. 
Fecha-se com o "vagalumes", uma luz que irrompe num repente, imagem, inclusive, que aparece no fim de outra narrativa de Primeiras Estórias ("As margens da Alegria" - que analisaremos mais adiante), e aqui encontramos o paralelo da questão do pensar mítico de que falava Rama, tratado no primeiro capítulo, ou seja, do mito que irrompe na estória com a pujança do que é "verdadeiro", como sublinha o próprio narrador quando abre, ao final, espaço para que se termine a "verdadeira estória".

Vaga-lume e trovão confluem-se no mesmo clarão, a chuva volta, mas todos já dispõem dos guarda-chuvas, os quais são abertos no caminho de volta para casa, após a retomada do enigma inicial, desta vez não mais como uma dúvida, mas já como certeza: "Mamãe, agora eu sei, mais: que ovo só se parece, mesmo, é com um espeto"(p. 175)

\subsection{Quando não se entende coisa alguma é que o sentido dado está:}

Em "A menina de lá" tomamos contato com Nhinhinha, uma menina de menos de quatro anos, muito miúda e com um comportamento atípico para uma criança de sua idade: não lhe atraíam os brinquedos ou bonecas, era geralmente quieta, não se mexia muito e permanecia, geralmente, sentada onde se achasse. Além disso, as pessoas não compreendiam muito bem suas poucas falas, menos pela estranhez e mais pelo inusitado, pelo imprevisto ou em expressão do narrador: "pelo esquisito do juízo ou enfeitado do sentido" (p. 67)

Vive com o pai, pequeno sitiante, a mãe, uma urucuiana, ao que parece, bastante religiosa (a mãe vivia com o terço na mão) e uma tia. Sua presença no 
meio familiar é muito discreta, não incomoda e nem é notada pelos adultos, mesmo quando, vez ou outra, irrompia numa fala, preeenchida com estórias absurdas e vagas.

O único que parece notá-la é o narrador, ${ }^{22}$ que embora não se coloque como personagem participante da trama, ou seja, não há nenhum momento em que ele interaja com outras personagens que não seja a menina, tampouco interfere nos acontecimentos, deixa escapar em alguns momentos uma proximidade com a garota: "E Nhinhinha gostava de mim" (p. 68) e afigura-se como o único que, inicialmente, põe-se a escutá-la.

Até que, em determinado momento da narrativa, o silêncio efetua um câmbio entre as personagens. Certa manhã, Nnhinhinha expressa um desejo, diz que queria um sapo vir ali e, algumas instantes depois, um sapo entra na casa; a menina, em tons de enigma e ironia, lança: "Está trabalhando um feitiço..." (p. 69), ao que todos pasmam e silenciam.

A partir deste instante, a situação repete-se constantemente, a menina expressa um desejo e, súbito, ele acontece. A família em não saber lidar com a situação e temendo o alarde, com a vinda de curiosos, de padres querendo cuidar de Nhinhinha, optam por esconder o fato.

22 Sobre o vínculo do narrador com a personagem é possível levantar mais uma hipótese, especulativa, é verdade, porque isto não se explicita, mas num dado momento da narrativa o narrador que inicialmente referia-se aos membros da família como a mãe, o pai, passa a tratá-los com mais proximidade: "Mas o respeito que tinha por Mãe e Pai, parecia uma engraçada espécie de tolerância" (p. 68), ou ainda, "Nem Mãe, nem Pai acharam logo a maravilha [...]" (p. 69), o que indicaria uma possível fraternidade. Trazemos tal hipótese à leitura porque esta posição do narrador poderia ser um dos determinantes à aceitação da atmosfera dos milagres do conto, ou, em termos do universo teórico percorrido, da maior aproximação entre narrador e o material mitológico que estrutura a narrativa. 
O caso da garota é tomado, então, pela esfera do milagre e a família não pretende mais explicar o que ocorre, mas no pensamento do pai, por exemplo, enxergam a possibilidade de tirar o "sensato proveito da situação": depois de um período de seca, ameaçando "estorricar o brejo", pedem a Nhinhinha que deseje a chuva, mas a menina não obedece, mesmo quando a lembram que se não o fizer, acaba-se tudo: leite, feijão, arroz, carne, enfim, itens indispensáveis ao imediato daquela existência.

No entanto, dois dias depois do pedido a menina deseja o "arco-íris" e como consequência, chove. Vemos na resolução deste conflito os impasses colocados à esta imaginação fértil: as personagens adultas, e mesmo o narrador que a esta altura encontra-se mais distante (“Nunca mais vi Nhinhinha” - p. 69), precisam de algo concreto, imediato, útil para justificar os milagres da menina.

Mas isto não é encontrado, no momento seguinte Nhinhinha morre, após desejar um "caixãozinho cor-de-rosa". Da morte, contudo, há a redenção, pois embora o pai se oponha, a princípio, acaba cedendo e a menina termina o conto como "Santa Nhinhinha" - desfaz-se o impacto da morte e a garota permanece viva na esfera do mágico-religioso.

\subsection{Para a grande cidade: harmonia como estrutura arquitetônica}

Sendo uma das preocupações deste texto discutir as intersecções entre imagens identitárias ligadas à nacionalidade e a presença do intento harmonizador no projeto estético de Guimarães Rosa, sobretudo em Primeiras Estórias, elegemos 
os contos "As margens da Alegria" e "Os cimos", narrativas, respectivamente, inicial e final do livro, para uma leitura não tanto no plano da recriação, como as anteriores, mas onde se explicitasse, de maneira mais enfática, os possíveis lugares onde estariam situadas as estórias protagonizadas por personagens infantis do livro entre as narrativas em que estão representados dados da identidade brasileira.

Os contos tematizam, ambos, viagens que um menino - que no decorrer das narrativas, torna-se o Menino -, realiza para o lugar onde se construía a "grande cidade", que embora não esteja denominada, dá fortes indícios - por referências espaciais: uma cidade sendo construída no semi-ermo, no chapadão, na planitude; como pelos julgamentos: "a cidade mais levantada do mundo" - de que seja Brasília. $^{23}$

Em Comunidades Imaginadas, Benedict Anderson refletindo, em determinado momento, sobre as temporalidades e a historicidade da nação e de conceitos de nacionalismo, centra o debate a partir de uma leitura do romance El Perequillo Sarniento, de José Joaquín Fernandez de Lizardi (apontado, por ele, como o primeiro romance de cunho nacionalista latino-americano), no qual seria possível observar "a imaginação nacional atuando no movimento de um herói solitário, percorrendo uma paisagem sociológica de uma fixidez que amalgama o mundo interno do romance ao mundo externo" (ANDERSON, 2008, P. 61).

Obviamente não pretendemos, aqui, situar os contos como nacionalistas, no entanto, é válido o esforço de isolar e deslocar o que Anderson aponta como traço

23 Alguns estudos críticos corroboram para esta leitura do espaço dos contos, dentre eles o artigo de Benjamin Abdala Junior, "A cidade mais levantada do mundo" - presente no livro Fronteiras Múltiplas, identidades plurais: um ensaio sobre mestiçagem e hibridismo cultural - e com o qual dialogaremos em alguns momentos desta leitura. 
comum de algumas narrativas "nacionalistas", a saber, o herói que em movimento, em viagem, observa, gesta e representa os anseios de uma imaginação nacional, para lançar luz às ambiguidades que se encenam nos contos elegidos para a leitura, ou seja, como um evento de intento nacionalista (e ufanista) como era a construção de Brasília, se dá ao olhar deste menino que percorre estas paisagens, ou seja, como o mundo externo é fixado no interno da narrativa.

No primeiro conto, o Menino fará uma viagem "inventada na feliz", ao que tudo indica, para passar as férias com os tios - "la um menino, com os Tios, passar dias onde se construía a grande cidade" (p.49)

Assim, segue no avião, envolto numa atmosfera de "harmonia prévia, benfazeja" o garoto tem todas as atenções voltadas para si: o piloto do avião conversa com ele, o tio mostrava-Ihe como se reclinava o acento e fazia promessas de muitas brincadeiras e coisas a serem vistas quando chegassem, a tia oferecia-lhe doces e sanduíches, e como consequência de tantos cuidados, o Menino seguia confortável, com "as satisfações antes da consciência das necessidades" (p. 51)

Chegando à casa dos tios, o Menino fica encantado com tudo que vê, árvores, flores, uma mata da qual ele imagina poderem sair índios, onças, leões, caçadores, ou seja, um olhar que se amplia na imaginação do exotismo que aquela paisagem possa oferecer-Ihe.

No entanto, nada disso sai da mata, apenas uma grande surpresa: o peru, em sua imagem imperial, imponente, "belo, belo, para sempre", que deixa o menino estupefato, mal cabendo-se em si, num transbordamento. E na imagem desta ave já podemos pontuar algumas das perguntas que nos oferecem o texto: toda a 
grandiosidade do peru guarda um paralelo com a noção de que nesta passagem para a modernidade, com o advento da grande cidade, seria possível, ainda assim, guardar a estabilidade nesta figura imperial, que substitui o caos que poderia surgir nestas "matas" desconhecidas - a "ferocidade" de animais e índios - e aparece para organizar a visão e o universo do Menino. Os contos, seguiriam desta forma, uma ambientação distinta daquela proposta para a maior parte da ficção rosiana, onde o espaço de excelência, e onde são pensadas as contradições do processo de modernização brasileiro, é o sertão, como o observa Marli Fantini:

Diferentemente de Brasília - o modelo mais emblemático de modernidade brasileira -, nas comunidades literárias de Guimarães Rosa, o processo de modernização ocorre sob o vetor intersubjetivo que conjuga tradição e modernidade, restauração e renovação, coletividade e subjetividade. (FANTINI, 2003, p. 108)

Residiria, aí, uma das primeiras ambiguidades deste conto de Primeiras Estórias, ou seja, o de escapar da concepção geral da obra rosiana sobre o conflito entre a modernização e a presença de tradições outras na sociedade brasileira. Os contos, caminhando nesta "contramão", colocam pari passu o olhar de encantamento do Menino e a euforia do projeto político de construção de uma nacionalidade brasileira ensejada em Brasília.

A cidade de Brasília, como é dado a saber, foi gestada a partir de um espírito triunfalista, pautada nos princípios de uma concepção arquitetônica universalista, que imaginava a nação sob a égide de uma modernidade urbana e ocidental, como observamos em Luiz Alberto Brandão Santos:

Brasília surge como símbolo da afirmação de uma nova era, como gesto de desafio, que pretende condensar e difundir a imagem de um 
Brasil-potência. Tratava-se de criar não apenas uma cidade, mas uma nova forma de organização social, nova cultua, nova sensibilidade: um homem novo (SANTOS, 2002, p. 87)

Destarte, constrói-se nestes contos de Guimarães Rosa o olhar deste homem novo, o qual é representado pelo Menino, recorrendo uma vez mais a Anderson, espécie de observador solitário que condensa em si a recepção desta nação imaginada a partir da alegoria da construção de Brasília.

Dadas as especificidades da personagem infantil, cabe-nos aqui, pensar os pontos de confluência entre o pensamento sobre a infância, a construção dessa personagem e sua associação ao entendimento de nação preconizado na construção da cidade. Neste sentido, serão-nos bastante férteis as reflexões de Marcos Cezar de Freitas, em ensaio de História Social da Infância no Brasil:

A criança, numa sociedade em permanente projeção para o futuro, destinada a vir-a-ser, facilmente tornou-se componente descritivo de um complexo social no qual o estar-em-formação da criança misturava-se a um estar-em-construção com o qual a "personalidade do país tornava-se objeto de reflexão. (FREITAS, 2003, p. 252)

Seguindo a trilha proposta por Freitas, a criança, e no presente trabalho, a personagem infantil no texto ficcional, se condensam na imagem da juventude da nação, onde o olhar de encantamento e a projeção a um futuro convergem para um projeto de formação identitária, ou como ainda afirma o autor, "a incompletude natural da criança é projetada como metáfora da nação inconclusa" (FREITAS, 2003, p. 253).

A este projeto soma-se a necessidade de criar um sentimento de comunidade, uma horizontalidade que pudesse dar conta de obliterar as diferenças, e convocar os indivíduos a participarem indistintamente de um projeto para a nação brasileira, que 
era hegemônico.

No entanto, paradoxalmente, tal horizontalidade é construída desde cima, ou seja, trata-se de um olhar alheio à maioria dos membros desta nação e pode ser observado também na maneira como nos é apresentado o olhar do Menino. Boa parte de suas observações e apontamentos sobre a cidade que se constrói fazem-se de dentro de um avião, ou seja, a partir do alto, onde: "Se homens, meninos, cavalos e bois - assim insetos?" (p. 50).

Retomando uma vez mais, a construção de Brasília, há que se considerar que se tratava de um projeto do Estado, o qual na conjuntura desenvolvimentista do governo de Juscelino Kubitschek (1956-1960) propunha um acelerado crescimento da cultura urbana, dificilmente acompanhado pelo "corpo" da nação. Isto reforça uma vez mais, o que dizíamos acima, sobre a distância entre o projeto de modernização da sociedade brasileira e as reais possibilidades dos membros desta mesma sociedade em acompanharem esta urbanização acelerada, e que somente um olhar distanciado poderia dar conta da euforia de um projeto de nação brasileira pautado na cultura urbana.

Esta é uma imagem que permitiria ler no conto uma adesão a este projeto de inserção do país na modernidade, todavia, na senda da leitura de Benjamin Abdala Junior, que vê no conto uma resposta irônica de Guimarães Rosa a toda a grandiosidade do projeto, há na estória um momento de instabilidade, pois depois daquele encantamento diante do peru, a que nos referimos há pouco, o Menino sai com os tios a um passeio e quando retorna, vai, sofregamente, buscar o peru, sendo acometido com a notícia de sua morte: 
'Ué, se matou. Amanhã não é o dia-de-anos do doutor?' Tudo perdia a eternidade e a certeza; num lufo, num átimo, da gente as mais belas coisas se roubavam. Como podiam? Por que tão de repente? Soubesse que ia acontecer assim, ao menos teria olhado mais o peru - aquele. O peru - seu desaparecer no espaço. Só no grão nulo de um minuto, o Menino recebia em si um miligrama de morte. (ROSA, 2001, pp. 52-33)

Neste momento, a morte do peru surge como o elemento que marca as perdas ocorrentes no decorrer da modernização, a paisagem que antes encantava o Menino, a partir de agora torna-se agressiva, e ele passa da alegria à "circuntristeza", numa espécie de renúncia à curiosidade, como diz o narrador. 0 miligrama de morte que recebe o desperta para o mundo maquinal, no qual a tradição e a modernidade não são tão conciliáveis ao ponto de não existirem as perdas.

O percurso de leitura indo de uma "aparente" adesão ao projeto para enfim colocá-lo em xeque, revelaria a ironia da narrativa, entretanto, há ainda um complicador: a narrativa não se encerra na morte do peru. Na última parte do conto, surge um sentimento ambíguo no Menino, que "se doía e se entusiasmava" (p.54) que vê, uma nova vez, o peru no quintal.

Não demora e já percebemos que não se trata do mesmo peru, mas outro, que ataca com voracidade os restos mortais do primeiro, metáfora da violência do processo, a tensão com que poderia terminar o conto desfaz-se no momento seguinte, em espécie de anti-clímax: surge uma luz verde, que brilha - "Sim, o vagalume, sim era lindo" (p. 55) - que devolve ao Menino a possibilidade de encantar-se, na ausência da possibilidade de congregação decorrente da morte do peru, esta nova possibilidade, traz de volta a harmonia e por fim, "Era outra vez em quando, a Alegria" (p.55) 
No segundo conto, o Menino realiza uma nova viagem para a casa dos tios: "Outra era a vez. De sorte que de novo o Menino viajava para o lugar onde as muitas mil pessoas faziam a grande cidade" (p. 224), mas aqui o motivo já não é passar uns dias divertindo-se, agora o Menino é retirado do convívio da família porque a mãe encontra-se doente, ao que parece num estado grave.

Desta vez já não há aquele encantamento da primeira narrativa, o Menino vai cansado, fingindo que sorria quando Ihe falavam. Há um tom de gravidade em seu entorno e ele percebe que os gracejos, as tentativas de animá-lo ou distrai-lo não são de todo sinceras, há sempre uma gravidade subjacente, simulada e de início já se anuncia que todos não estavam totalmente concentrados no Menino porque alguma coisa maior, grande, está por acontecer e o Menino intui que tal perigo relaciona-se à mãe.

O conto divide-se em quatro partes, assim nomeadas: "O inverso afastamento", "Aparecimento do pássaro", "O trabalho do pássaro" e "O desmedido momento", que alinhadas assim, sinalizam que a gravidade será também desfeita no conto.

$\mathrm{Na}$ primeira parte, mesmo na sua introspecção e tensão, faz-se mister destacar que o Menino leva consigo o seu brinquedo favorito: "um bonequinho macaquinho, de calças pardas e chapéu vermelho, alta pluma” (p. 54), todavia, sentindo-se culpado por saber que a mãe era ameaçada por um perigo, enquanto ele seguia com aquele brinquedo, engraçado e sem mudar, pensa que seria melhor jogá-lo fora, mas sente pena em desfazer-se de seu companheiro e opta por desprender-se apenas do chapéu do macaco. 
Diante desta primeira ruptura segue o Menino em sua viagem, e se no primeiro conto, a cidade aparecia em clima de vislumbramento, agora, era somente poeira, gente e terra, sem atrativos e sem despertar seus olhares curiosos. Aqui o olhar do Menino já não conflui com o projeto triunfalista e entusiasmado, mas com a construção, a materialização da cidade, que para ter seu lugar precisa por abaixo o que antes era uma paisagem vislumbrante para o garoto.

Enquanto isto, como o Menino já não se interessa pelas coisas que o rodeiam, o macaquinho converte-se, mais do que um brinquedo, em seu companheiro inseparável: "Mas o bonequinho macaquinho não era mais o para a mesa de cabeceira: era o camarada, no travesseiro, de barriguinha para cima, pernas estendidas. [...] O macaquinho, quase também, feito um muito velho menino" (ROSA, 2001, p. 227). Deste modo, novamente diante da iminência da perda, no caso a da mãe, o Menino encontra o refúgio na passagem do macaquinho a um "quase" velho menino.

Para além do macaquinho que amortiza os impactos da situação, surge, na segunda parte do conto, novamente a presença de um pássaro, desta vez, o tucano, para o qual vem os mesmos adjetivos destinados ao peru, sobretudo, o "belo". Desta vez, a suplantação não se restringe ao Menino, mas todos observam a ave e como ela anima ao Menino, fato que os leva a intentar prendê-la, ao que o garoto se opõe, pois acredita que a beleza está nas visitas matinais que faz o pássaro na mesma mata em que surgiu o peru da outra estória.

Na terceira parte da estória, há o retorno do encantamento e, agora, diferente do que ocorre com o macaquinho o Menino já não se sente culpado, mas a presença da ave enche-Ihe de esperança, a qual faz com que ele repita todo o 
tempo que a mãe está curada, que nunca esteve doente, o que, depois de quatro dias, confirma-se no telegrama recebido pelo tio: "A mãe estava bem, sarada! No seguinte - depois do derradeiro sol do tucano - voltariam para casa" (ROSA, 2001, p. 232).

Tudo caminha para que a harmonia prevaleça já neste momento do conto, quando na última parte surge uma nova "tensão", o Menino, no avião de volta para casa, dá-se conta de ter perdido o macaquinho, com o que é tomado por súbita seriedade e começa a chorar, pois a perda, mesmo que não fosse a esperada, realizara-se.

Contudo, recorrendo uma vez mais ao anti-clímax instala-se um nova surpresa no texto:

\footnotetext{
Mas, então, o moço ajudante do piloto veio trazer-lhe, de consolo, uma coisa: - "Espia, o que foi que eu achei, para Você!" - e era, desamarrotado, o chapeuzinho vermelho, de alta pluma, que ele, outro dia, tanto tinha jogado fora!

O menino não pôde mais atormentar-se de chorar. Só o rumor e o estar no avião o atontavam. [...] Não, o companheiro Macaquinho não estava perdido, no sem-fundo escuro do mundo, nem nunca. [...] O Menino sorriu do que sorriu, conforme de repente se sentia: para fora do caos pré-inicial, feito o desenglobar-se de uma nebulosa" (ROSA, 2001, p. 233)
}

Em suma, temos nos dois contos, entrepostos, numa leitura complementar, um percurso que mesmo evidenciando tensões, com a experiência ou iminência da morte, com perdas e rupturas, caminha sempre para um fim que consegue organizar isto a uma nova ordem, que é ao mesmo tempo a ordem inicial, o Menino sempre volta a seu lugar de origem após ter conciliado experiências conflitantes: "E o mais importante é o equilíbrio a que o Menino chega no final das duas narrativas, através da vivência de opostos que se conciliam, dando-lhe a medida mais complexa da 
vida”. (RESENDE, 1988, p. 33)

Pensando nas narrativas enquanto representações e possíveis interpretações das fronteiras das identidades nacionais, estas últimas serão diluídas, ou no limite, terão as suas contradições 'harmonizadas' por um discurso que se acredita emancipador, ao "desenglobar-se da nebulosa" ou no triunfo da Alegria, há sempre o espaço para uma certa ambiguidade que, de alguma maneira, minimiza as fissuras e oculta o que de violento há.

\section{4."Pirlimpsiquice": o mundo que se acaba na queda e (re)volta, são e glorioso}

Ainda, hoje adiante, anos, a gente se lembra: mas, mais do repente que da desordem, e menos da desordem do que do rumor. (Narrador de Pirlimpsiquice)

Assim, relativizando a "desordem" dos fatos é que o narrador de "Pirlimpsiquice" dá início ao relato da aventura de 12 garotos na montagem da peça "Os Filhos do Doutor Famoso". Tal fato se dá num colégio católico, ao que supomos, num espaço citadino, organizada pelo Dr. Perdigão, responsável por dirigir e ensaiar os garotos, com sua lente de "corografia e história-pátria" (p. 86).

Do drama a ser encenado não temos muitos detalhes, depreende-se, no entanto, ser uma dramatização clássica, a que conhecemos pela caracterização das personagens: um tal Doutor Famoso que tem quatro filhos bastante diferentes um dos outros - um padre, um militar (o capitão), um poeta, e um criminoso - e mais um delegado, um amigo do Doutor Famoso, o homem que sabia o segredo e dois policiais. Além disso, o drama deveria começar com recitados versos "que falavam 
na Virgem Padroeira e na Pátria”.

Para representar os personagens o Dr. Perdigão escolhia os alunos de acordo com características de suas personalidades que os aproximassem das personagens, faltando apenas uma função a um dos alunos, ao menino que é o narrador do conto, que segundo o Dr. Perdigão não servia a cena alguma, mas com a intervenção do padre Diretor, declarando que "aluno aplicado, e com voz variada, certa, de recitador" (p. 88) poderia converter-se num vantajoso ponto, isto é, Ihe caberia conhecer todo o drama para socorrer qualquer ator a que lhe falhasse a memória.

A tentativa do Dr. Perdigão em estabelecer imediatos paralelos entre os garotos e os personagens, somado ao fato de que há vários momentos em que são inseridas algumas máximas do Dr. Perdigão, principalmente de origem grega e latina - "Representar á aprender a viver além dos levianos sentimentos, na verdadeira dignidade"; "Longa é arte e breve a vida... - um preconício dos gregos" (p. 89); "Sus! Brio! Decoro e firmeza. Ad astra per aspera! Sempre dúcteis ao meu ensinamento...” (p. 90); "Senhores meus alunos... Ad augusta per angusta..." (p. 92) $)^{24}$ - , revela que seu intento não era a transposição destes modelos como princípio organizador apenas da representação cênica, mas também da educação dos meninos.

Pensando na questão identitária, uma das vias de leitura dos textos, subjaz até este momento do conto uma certa crítica à importação não refletida, criticada ou que tenha passado pelo viés da transformação criativa, de modelos externos, o que que na fala do narrador mostra-se impossível, inclusive, porque a "personalidade"

24 Ambas expressões latinas citadas aqui têm um sentido que as aproxima da ideia de uma travessia, que por um caminho arduoso tem um destino promissor - Ad astra per aspera: Aos astros por meios ásperos; Ad augusta per angusta: Ao sublime pela dificuldade. 
dos meninos também simulava-se (era, antes de mais nada, uma interpretação), no contexto do colégio:

Inquietávamo-nos, não fossem destituir-nos daquele sonho. ĺamos proceder muito bem, até o dia da festa, não fumar escondido, não conversar nas filas, esquivar o mínimo pito, dar atenção nas aulas. Os que não éramos "Filhos de Maria", interpretávamos fazer parte. (ROSA, 2001, pp. 89-90)

Para além disso, a impossibilidade de tal feito confirma-se no restante da narrativa, também pelo "indesfecho" da representação da peça "Os filhos do Dr. Famoso", anunciado pelo narrador já no início do conto.

Entre os garotos que representariam a peça há Zé Boné, menino que "regulava de papalvo" (p.87) e vivia pelo colégio a imitar os filmes de faroeste, onde representava, ao mesmo tempo, a moça, o mocinho, o xerife e os bandidos, conseguindo, ainda, beijar-se no final. Todos acreditavam ser Zé Boné investido em loucura e temiam que o menino, sem ajuizar-se, divulgasse o drama que representariam, cujos detalhes deveriam ser mantidos em segredo até o dia da encenação.

Entretanto, mal começam os ensaios e os atores veem-se entre risos e troças, pois os alunos que não participavam da peça, divulgavam o que afirmavam ser a "verdadeira estória do drama", que segundo o narrador, apesar de mentirosa, era completa e bem aprontada. Um outro garoto, Gamboa, e não o parvo Zé Boné a divulgara e afirmava com convicção ser aquela, realmente, a versão que seria encenada. Optou-se, então, por criar um novo drama, paralelo, inventado, e dar divulgação dele, tanto para proteger "o verdadeiro", quanto para desmentir a versão de Gamboa. 
Mesmo com estes dois novos dramas para tentar manter em sigilo o drama do Dr. Famoso, eis que começa a circular no colégio cenas do "legítimo", divulgadas não por Zé Boné, mas por outro garoto, ao qual não podem repreender: "Só que, no Alfeu, mesmo pós-festa, não se podia meter o braço: ele furtava, para a gente, pão, doces, chocolate, coisas da cozinha dos padres" (p. 91) e a única estratégia para assegurar o sigilo da peça seria "alugar" o silêncio de Alfeu, já que restavam apenas três dias para a encenação, isto é, o que poderia configurar-se no maior conflito, a perda daquilo que os meninos mais desejavam preservar (o segredo do drama), é apaziguado, pois existem interesses mais imediatos e particulares, cuja continuidade, faz-os colocar em risco o "patrimônio" coletivo

Tudo isto corrobora a uma crítica subjacente à inconciliação de aportes "externos" (a ordem do Dr. Perdigão, o drama que pouco tem a ver com os garotos, o paralelismo imediato entre um universo clássico e a realidade do colégio) com a experiência dos garotos, como àquela que apareceria, segundo Rama, na narrativa de transculturadores.

É preciso uma transformação criativa e ela surgirá através de um imprevisto: o pai do garoto que faria o personagem principal está à beira da morte e o menino precisa viajar. Como solução há todo um rearranjo da peça: o Dr. Perdigão, solene professor, acaba por assumir o lugar do ponto e este último ocupará o lugar do ator ausente. Ocorre, contudo, que somente no início da encenação todos se dão conta de que apenas o Ataualpa, protagonista ausente, havia decorado os poemas que deveriam ser declamados na abertura da peça.

Assim, o "ponto" fica paralisado diante do público, e sem saber o poema e como sair daquela situação grita: "Viva a Virgem e viva a Pátria" (p. 94), ao que 
segue uma vaia, uma tentativa frustrada de baixar as cortinas (que infortunadamente enguiçam) e um coro, para surpresa de todos, clamando por Zé Boné.

Zé Boné pula no palco e puxa a representação de uma mistura entre o drama do Gamboa e aquele que inventaram para ocultar a peça original ao que público responde com silêncio e com uma apreciação do que via.

O novo drama surgido na interpretação dos meninos, lido no nível da estruturação literária, seria então aquele em que emerge a criatividade e a capacidade de congregar elementos de forma a construir um todo, ainda que contraditório, harmônico, em resposta à imposição da peça proposta pelo professor.

No entanto, há um problema: para o novo drama não foi pensado um fim, ou seja, a fabulação ficaria em suspenso, seguindo seu curso, enquanto os meninos pudessem continuar no palco. O narrador, diante do impasse, toma a decisão da ruptura total: atira-se do palco numa cambalhota, estatelando-se no chão e deixando a todos, público e atores paralisados.

O trágico desfecho sinaliza, num primeiro momento a leitura do conhecimento das limitações na tarefa de uma criação literária correspondente à "missão" de estabelecer uma nova ordem ao caos de uma formação cultural híbrida, resumida na frase do narrador: "E, me parece, o mundo se acabou". Todavia o desfecho revertese em "indesfecho" como anunciado no início da narrativa e no outro dia, o narrador ressurge "glorioso".

O conto segue, desta forma, um movimento de negação a uma importação pacífica, passando pela emergência da criatividade e o reconhecimento de suas limitações, para se abrir, no fim, a um recomeço conciliador. 


\subsection{Para Tetembuatubia: os de cá, os de lá}

Diante dos caminhos interpretativos que podem ser tomados para a leitura da criança como significante da construção de uma imaginação nacional no contexto angolano, acreditamos ser a via da ruptura e da emergência da violência a que mais se destaca no texto de Luandino. Contudo, na primeira das três estórias, podemos observar, entre motivações utópicas, que a narrativa escapa do essencialmente vivido e abre-se à criação de um universo simbólico, como o ponto de partida em que o leitor possa notar "a antiga unidade escrava virando misturas forras" (p. 31)

O conto, como "Partida do Audaz Navegante" de Guimarães Rosa, que analisamos há pouco, tematiza o percurso de crianças que estão brincando e seguem numa espécie de travessia com a intervenção da fábula naquela cena cotidiana. Todavia, ao observarmos, a construção e caracterização das personagens já temos algumas pistas para a leitura em que nos propusemos a comparar a emergência da harmonia e da violência num e noutro autor.

"Lá em Tetembuatubia" começa numa tarde em que o narrador anuncia que "queria chegar nos delás onde nem bem que sabia certo" (p. 15), onde damos encontro a um grupo de garotos que nus, entre meio capins, meias areias, entregam-se às "toscas brincadeiras": estão masturbando-se uns aos outros e os que não aceitam ou vacilam em aceitar são sancionados verbal e fisicamente.

Interessante para pensar o elemento da brutalidade que surge entre as brincadeiras é observarmos o princípio que as rege, encerrado na seguinte fala de Neca, um dos garotos, aparentemente o mais forte, que acabava por comandar os 
outros: "Quem que não fizer assim-assado... mãe dele é isto-aquilo! - e sangue de cadaqual manda defender nome de mãe, nem que é com a morte do outro mesmo" (p. 16).

Na sequência são apresentados os outros meninos: Boi, que já se insere na cena caracterizado como bruto, que só emitia "urritos monossilábicos" e masturbavase com as duas mãos; Toninho, que ria de tudo; Mará, que aceitava tudo; Zemaria e Kalubém que aparecem como os "piores de todos" querendo sempre mandar nos demais; e o narrador, que afirma ter a inocência à época da infância, mas "as piores vergonhas depois, no já sabido" (p. 17).

De toscas, as brincadeiras convertem-se em turvas e os meninos já se encontram em "guerras do bem e do mal" e cumpre destacar que não há uma oposição do bem contra o mal, mas ambos são colocados lado a lado, constituindo a tensão e definindo-os.

Dá-se, então, a primeira censura ao cenário que se formava: surge Zeca, filho de um sapateiro que assobiava salmos e que "era a sombra no deserto do pecado com suas estórias moralistas" e decreta aos meninos: "Euê!? Sodoma e Gomorraé!..." (p. 18), os meninos procuram recomporem-se e suspender as "brincadeiras", mas Neca, o que sempre mandava, ressurge em tons de ameaça novamente: "Tens nada com isso? É sentença! Quem que não fizer, mãe dele...” (p. 18).

Mas o conto continua nas trilhas do bem e do mal e tanto os intentos de Zeca, como os do narrador, que procura convocar uma outra brincadeira mais amena, são vãos, pois Neca que mandava nos demais sentencia que se inicie a tortura com Zeca: 
Se amarrava o catembo, cortava-se o rabo vaidoso. Saía a tortura: logo-logo apertar ovos nus dele, até dar suores de dor; lhe mijar em boca. Mas nada: estóico cristão no circo, nós palermas românicos, ele nunca que bufava. Aí o Neca, raivento da luz do outro, mandava crueldades fora das leis da séria brincadeira - e a gente víamos cuspos dele, babosos, nos rés dos dentes, todo ele gozos. (VIEIRA, 2005, pp. 19-20)

Apesar do cenário, neste conto ainda pairam alguns questionamentos sobre a intervenção da fábula como contraponto ao conflito, o que se dá com a presença de Turito (alter-ego de Zeca), o menino refazeiro de mundos, que numa brincadeira com pipas multicoloridas irá propor a viagem para Tetembuatubia, planeta alheio. Neste momento do conto, a linguagem torna-se personagem e a força da palavra de Turito é capaz de criar um novo mundo, o planeta Tetembuatubia.

Michel Laban, que dedicou muitos de seus estudos a compreender a obra de Luandiano Vieira, em ensaio sobre a procura da identidade em No antigamente, na vida dirá que no conjunto das estórias o que se evidencia é uma atmosfera de exacerbação do conflito, no entanto, para o autor, "Lá, em Tetembuatubia" é a estória que consegue guardar uma imensa esperança, mesmo já apontando os caminhos para a identidade fragmentada que será retratada nos demais contos:

Cependant, il convient de remarquer que la realisation de cette
espérance ne peut se faire que sur une autre planète, Tetembuatubia,
l'Etoile de Feu, loin de la pauvre realité des quartiers populaires de la
ceinture de Luanda. Lá, em Tetembuatubia apparaît donc plus
comme une aspiration que comme l'évocation symbolique d'une
experience vécue. (LABAN, 1985, p. 81$)^{25}$ Sendo assim, mesmo com a presença da violência do mundo cindido dos

25 Em livre tradução: Contudo, deve-se frisar que a realização desta esperança não pode se realizar, senão em outro planeta, Tetembuatubia, a estrela de fogo, longe da pobre realidade dos bairros populares da periferia de Luanda. Lá, em Tetembuatubia, portanto, aparece mais como uma aspiração que como a evocação simbólica de uma experiência vivida. 
garotos - à época lida, sobretudo, em consonância com as imposições da situação colonial - , observa-se nesta primeira, a idealização de um lugar onde houvesse as condições para a construção e a presentificação de uma utopia de liberdade, já que Luandino Vieira, em colocação de Laura Cavalcante Padilha, pode ser visto como um dos "arquitetos intelectuais do sonho de uma terra livre e desperta"(PADILHA, 2002, p. 43).

Todavia, é importante ressaltar que a imaginação da nação onde seria possível a convivência longe da violência se dá em outro planeta, ou seja, de alguma maneira o autor já deixar vislumbrar, mesmo nesta estória, que esta construção não pode ser harmônica a não ser na perspectiva utópica, metaforizada na imagem do voo na pipa multicolorida que abarca diferentes garotos em seus distintos quadrantes, levando todos para este mundo possível:

Porque Tetembuatubia era o inconsumível mundo de distâncias muito curtas, crescendo em solas de nossos pés descalços, sempre de sem beiras, sem meias, confins todos paralelos, para lá, para adiante, se abrindo. $E$ se fechava atrás de nós, gente éramos os que levávamos a candeia de toda a luz, no atrás virava trevas do nada onde que tínhamos saído, mundo infeito ainda outra vez, Tetembuatubia sempre só sendo o que a gente ainda nem éramos (VIEIRA, 2005, p. 47)

Em contrapartida, este "o que ainda nem éramos" será trazido à tona em dois eventos, que dão pinceladas de realidade às cores amigadas das pipas que os levavam para Tetembuatubia e que, em momento de suspensão anulava as diferenças entre os meninos.

Primeiramente, eles dão encontro a outras pipas disputando espaço com eles, os do musseque do Makulusu ${ }^{26}$, dos quais não gostavam muito, por tratar-se de

26 No conto, embora isto não seja afirmado explicitamente, há referências indicando que os meninos que o protagonizam vivem no musseque do Kinaxixi, daí surgir a rivalidade, neste momento, com 
"uma planeta guerreento" e os do Ingombota, que inserem a tensão racial no conto. Até o momento, quando iam para Tetembuatubia, as diferenças entre os meninos, com a presença de brancos e negros não era um problema, mas os meninos do Ingombota chamam atenção para isto, gritando em quimbundo, para que fugissem os brancos ordinários, evidenciando que não eram todos iguais e que não podiam ignorar este fato.

De modo que temos, mesmo constatando esta atmosfera onírica, a violência e a tensão ocupando lugar central na narrativa, daí considerarmos este sonho calcado numa realidade que se faz por cortes, como se do chão vermelho dos musseques, por onde deslizam esses garotos, é que fosse retirado o material para a construção do outro planeta, o que nos leva a considerar a utopia na perspectiva de Ernst Bloch, ou seja, a de uma utopia libertária calcada no "sonho diurno", que seria:

[...]antes de tudo o interesse revolucionário, com seu conhecimento de como está ruim o mundo e seu [do artista] reconhecimento do quanto ele poderia ser bom como um outro mundo, que necessita do sonho desperto para a melhoria do mundo"( BLOCH, 2005, p. 97).

Utilizando-nos uma vez, mais da metáfora proposta por Bosi entre céu e inferno, a presença da violência nesta estória anularia o percurso que vai do "Inferno" ao "Céu", instaurando uma conflituosa convivência de ambos, apontando para a ambientação tensa que predominará no restante do livro.

Deste modo, o recurso de inscrever na infância o desejo de construção da nação angolana, no período da descolonização, considerará tanto o lá (plano da liberdade) que se almeja, quanto o cá que se impõe (presença colonial a ser 
combatida).

\subsection{Dinito, o verdadeiramente mau}

Se em "Lá, em Tetembuatubia", os meninos eram definidos pelo bem ou pelo mau, e ainda podemos observar impulsos utópicos, aqui o mal ganha a cena, Dinito, o personagem central e narrador do conto, define-se, em diversas passagens, como verdadeiramente mau, assim, pensando em crianças como imagens de futuro, deflagra como afirma Tania Macêdo (2008), a violência dos tempos que viriam.

Se Dinito é um menino que tem a personalidade definida pela maldade, ao mesmo tempo, sua caracterização traz o conflito de um desejo por definir-se enquanto angolano, preservando os valores, que para ele seriam a expressão desta identidade fragmentada.

A violência da imposição de valores externos, justificada pela necessidade de efetivar a missão civilizadora é dada a conhecer já na primeira página do conto: "Quem errava levava surra da menina Glória - ela não gostava o mundo torto, queria tudo bem feito, nem que é à porrada mesmo é preciso civilizar estes gentios" (p. 61).

Aparece, assim, outra personagem importante no conto: a professora ${ }^{27}$, que indica de forma exemplar os impasses de um sistema educacional que privilegiava a visão de mundo do colonizador, em detrimento dos elementos autóctones.

27 Em entrevista a Michel Laban, Luandino Vieira afirmou ser esta personagem inspirada no conto "A menina Vitória", do também escritor angolano Arnaldo Santos, conto em que a professora é retratada como aquela que impõe, através de um discurso autoritário e discriminatório, valores pregados pela educação formal portuguesa em Angola. In: SANTOS, Arnaldo. Prosas. Luanda: União dos Escritores Angolanos, 1985. 
Em dado momento do conto, a menina Glória pede a Dinito que faça a leitura de uma redação, na qual aparece a palavra gorda, com duas possibilidades de pronúncia, naquele contexto, quanto à sua tonicidade: "gôrda" para a norma padrão, "górda" no sotaque mussecado de Dinito: "musseco ainda as vogais, quero ouvir eu mesmo, ser tudo como no antigamente" (p. 71). Na continuidade da cena, a professora pede a Dinito, que não leia como um negro, com a interferência do quimbundo e, após ser repreendido, o garoto lê na pronúncia "correta", ao que a professora responde: "Assim é que é, não deves dizer como os pretos". No entanto, ele já não quer prosseguir a leitura, sente vergonha, terminando por se utilizar, uma vez mais, da fala dos musseques: "e eu assotaco minha raiva na frase sublinhada".

Esta raiva de que nos fala a personagem a mobilizar o seu sotaque é síntese da violência que como afirma Fanon, está já no cérebro do colonizado, e que será necessária à mobilização da revolta, do desejo de libertar-se, reescrevendo a cultura que foi subjugada na situação colonial. Demonstra, também, o rompimento de binarismos impostos pelo discurso colonial para dar lugar a um discurso que fala de identidades capazes de mobilizar a ancestralidade juntamente com a própria matéria da opressão para a instauração de novas formas de expressão e singularização, ou ainda, como expresso em Bahbha, com o lugar da diferença, o espaço do adversário não estando de fora e nem em total oposição, mas podendo ser aproveitado para se afirmar a desejada alteridade.

Como nos outros contos o sujeito também não sairá ileso dessa negociação de seus valores, pois a violência não engendra apenas sua revolta, mas já faz parte de todas as suas ações e seu cotidiano é marcado por ela, e nesta senda, o conto traz uma nova face da maldade de Dinito, que por ciúmes de Xana, garota pela qual 
está apaixonado, irá matar o seu melhor amigo:

Ele [Candinho] sabia tudo (...). Só não sabia que vou-lhe matar; ninguém que Ihe avisou; é pena. Eu queria matar para tu veres que sou mau, cuspir nas sagradas entranhas do dia feriado mundial; mas queria ele vivo comigo nos pássaros do crepúsculo de nossa lagoa voltando nas asas deles.

E matei. (VIEIRA, 2005, p. 78).

O assassinato de Candinho é narrado sob uma dupla perspectiva: Dinito, que acredita na sua pura maldade, e na prova digital que possui em suas mãos com o sangue do amigo; e a versão da comunidade, que acredita que o menino, Candinho, foi levado pela lagoa por razões sobrenaturais.

Termina-se assim, com a lagoa engordada pelo sangue de Candinho, fruto tanto da revolta, como das perdas assumidas neste processo, marcando que tal violência, está a modular atitudes e gestos. O sangue, contudo, permanece por toda a vida, segundo Dinito, que encerra a violência de uma constante luta na frase final do conto: "nunca nos deixaremos domestica, juro!" (p. 107).

\section{7. "Memória Narrativa ao Sol do Kinaxixi” - a beleza suspendida em três tempos de violência}

Urânia - um soletrado nome só e é a verdade mesmo? Ou Ihe nasci ainda, mentira de minha vontade, sonho? Mas tem o sangue, tem o sol, tem o Xôa - e no meu pulso a cicatriz d'amizade.

Entre a verdade e o sonho, somos lançado à experiência de Dinho, menino protagonista da última das três estórias de No Antigamente, na vida: seu encontro com a menina Ura, narrado em três versões, numa atmosfera de beleza - a do lá, das verdes pastagens do "sonho quinaxíxico" - e sangue - de cá, da bruta queda 
em meio aos meninos que em terras vermelhas seguem a espantar a vida.

Numa caminhada entre o Kinaxixi e o Makulusu - musseque "alheio" -, cujo percurso Dinho demonstra conhecer muito bem, para a surpresa da personagem, ele encontra-se, de repente, perdido - dá-se neste momento o encontro com o sonho, ouve chamar o seu nome e é ela, a menina Ura, presentificação da beleza, "flor no vaso da virtude" (p. 121).

O encontro proporciona ao menino tamanha comoção e comunhão com a menina, que seu mundo, o sol de seu Kinaxixi reveste-se em brutas trevas e como o Turito de "Lá, em Tetembuatubia", a menina Ura, num jogo de palavras e exploração de suas significações, faz-lhe esquecer as palavras feias, trazidas à cena, emblematicamente, pela figura da menina Glória, a professora que aparece em "Estória d'água gorda", cujo intento assimilativo aos padrões da missão civilizatória portuguesa tolhia aos meninos qualquer manifestação comportamental ou linguística que os afastasse dos ditos padrões.

Além disso, ao espaço onírico sobressai-se a possibilidade de afirmação da identidade cultural, na medida em que a menina Ura evoca a kianda, figura central ao imaginário da cidade de Luanda, evocada como aquela que guarda as águas da capital angolana, ou seja, uma figura que remete à singularidade da cultura angolana, aparece na narrativa no momento dedicado a explorar um espaço possível de afirmação da diferença, como acompanhamos com Laban: "Ele, também, com o aparecimento da sereia do Kinaxixi, refugia-se em um mundo irreal onde a sua auto-proclamação da identidade cultural não está susceptível a contestações"28 (LABAN, 1985, p.82)

28 No original: "Lui aussi, avec l'apparition de la sirène de Kinaxixi, se réfugie dans un monde irréel où son auto-proclamation d'identité culturelle ne risque pas d'être contestée" 
Voltando à lembrança da menina Glória, ela cumpre ainda um papel importante e simbólico na estruturação da narrativa e para os paralelos entre o que se representa na obra de arte e contexto social angolano: retira a personagem da atmosfera que o protegia das contestações à sua identidade, como afirmou Laban, no momento em que antecipa a queda na armadilha colocada pelos outros meninos, colegas de escola, concomitante à suspensão do sonho: "A bruta queda, incêndio de estrelas, noite. E o riso, gritos, assobios - minha bata suja, amussecada, joelhos verdes de deus de bronze caído na simples armadilha de capim amarrado." (p. 122).

Passa-se, neste instante, da violência recordada na figura da menina Glória para a violência física exercida pelos meninos, entre os quais, vemos repetidos alguns personagens da segunda narrativa do livro: Gigi - do qual gostaria de ser amigo, mas encontram-se em campos opostos da vida e Dinito - com a sua maldade ainda mais frisada, maldade pura como vemos repetidas vezes no conto.

Da saída da armadilha dispara-se a segunda narração do encontro com a menina Ura, motivada pela ameaça de Dinito, que decretara não irem os meninos à escola (ao Dinito ninguém ousava desobedecer, e isto é lembrado com a afirmação do assassinato do amigo Candinho, em "Estória d'água gorda"), e pelo desejo de Dinho em vingar-se dos meninos de alguma forma, contando-lhes o encontro com a kianda, que causaria inveja e admiração.

A esta altura, a linguagem torna-se personagem e narrar acaba sendo o pretexto para escrever/inscrever sua singularidade, expectadores (Gigi, Dinito, e posteriormente Zeca, que chega sem deixar-se perceber) intervêm na fabulação trazendo todo o imaginário sobre a kianda, estórias vistas, vividas e ouvidas passam a compor o relato e nele fica a mensagem: é preciso escrever aquilo que nos define, 
manter viva a estória da kianda significa manter-nos vivos, como vemos na fala atribuída à menina Ura:

Do lado de cá [o espaço onírico do encontro] é que encontramos as belezices... - a menina me segurando minha mão no escuro rio. Do lado de lá que só temos a morte - ela me adiantou ensinar. (VIEIRA, 2005, p. 128)

Uma segunda vez Dinho é arrancado deste mundo de possibilidades com a intervenção de uma violência manifesta contra ele: surge Xôa, uma espécie de liderança entre os meninos. Deste novo encontro, entremeado por desafios físicos, sacrifícios de animais, torturas, Dinho decide-se por utilizar uma vez mais o recurso da narrativa de seu encontro com Ura para escapar da situação.

Contudo, desta vez, ao invés de uma comunhão com os meninos, o que ocorre é que Dinho percebe o medo de Xôa, achando ser a kianda uma espécie de cazumbi (alma do outro mundo), aproveitando-se do fato para paralisar os gestos deste último, a narrativa transforma-se ela também em instrumento de violência.

Procurando minimizar o impacto e deslegitimar o relato, Xôa associa a menina Ura à fealdade, o que dispara a raiva de Dinho que the propõe uma luta, mesmo sabendo dos riscos de tal empreitada e, como das outras vezes, a intervenção do universo simbólico da kianda no cotidiano dos meninos é interrompida pelo embate, do qual, o narrador acreditando não ser mais necessário descrever pois "o sangue já secou, o coração não ferve mais", fecha no "resumo só: venceu ele, me derrotei eu" (p. 162)

Observamos que a derrota ao final do conto não se deve apenas ao fato de Dinho ter perdido a luta e dela saído ferido, mas ele também derrotou-se a si próprio, quando assume as dificuldades e os cortes de sua construção identitária e sua 
veiculação a valores "tradicionais", ou seja, assume que a violência do processo que em dada medida implica a fragmentação do próprio sujeito. 


\section{Considerações Finais}

O percurso de leitura deste trabalho seguiu caminhos que intentavam evidenciar que partindo de similaridades é possível desembocar numa pluralidade,, seguindo de perto as considerações da estudiosa Maria Aparecida Santilli (2003) a despeito da crítica que tenha se ocupado das obras de João Guimarães Rosa e José Luandino Vieira, a qual afirma que dos pontos comuns aos textos é que se afundam suas especificidades.

Assim é que foram tomados os textos de No antigamente, na vida e de Primeiras Estórias, num primeiro instante, identificando o comum dos autores enquanto (re)criadores, procurando em seu texto uma escrita que fosse capaz de representar um desejo emancipatório e singularizador para as literaturas produzidas em seus países, não desconsiderando a manipulação criativa de diversas fontes, instaurando, como o chama Silviano Santiago, um entre-lugar para suas expressões: "entre o sacrifício e o jogo, entre a prisão e a transgressão, entre a submissão ao código e a agressão, entre a obediência e a rebelião, entre a assimilação e a expressão [...] “(SANTIAGO, 2000, p.26).

Ainda sobre este aspecto, fizemos uma leitura procurando aproximar as conceituações de Rama sobre a transculturação e os estudos sobre as literaturas africanas de língua portuguesa que se detivessem, sobremaneira, ao mapeamento da construção da linguagem literária de seus autores, no intento de lançar luz sobre a (re)criações destes escritores, e pudemos observar, que mesmo diante de um impasse a princípio comum, que seja o manejo de distintas fontes e um esforço 
independentizador para esta leitura, tanto o projeto estético e os alinhamentos intelectuais e políticos dos escritores desembocavam em respostas bastante diferentes.

Luandino Vieira afirmou, certa vez, em entrevista a Michel Laban, quando questionado sobre as influências da literatura brasileira que estariam na composição de sua escrita, ter-se apresentado na leitura de Guimarães Rosa, nomeadamente, em Sagarana, uma revelação: o caminho da liberdade na utilização da fala das personagens excêntricas, no sentido de estarem à margem. No entanto, se a liberdade é apreendida em Rosa, os destinos finais destes caminhos se apresentaram, ao menos nesta leitura, variados.

A partir daí começaram a evidenciar-se a diferenças, identificadas, sobretudo, com a caracterização das personagens infantis, em Rosa, definidas pela alegria das coisas amanhecentes, como o captou Henrique Lisboa, e em Luandino Vieira, com a evidenciação da "temática da violência, consubstanciada em um mundo perverso em que o sangue, a morte, o assassinato cruel de pássaros e insetos [e deles próprios] cometidos pelos moleques são motivos constantes" (MACÊDO, 2008, p. 151).

Com a caracterização das crianças procuramos também compreender as construções das identidades nacionais de Brasil e Angola, procurando alguns ecos nos pensadores que se dedicaram a compreender as imbricações sociais e históricas destas reflexões, as quais foram os motes que percorremos durante o texto, compreensão que passou pela necessidade de retomar o discurso colonial, por vislumbrarmos sua presença entre tais reflexões.

Deste discurso retiramos as duas linhas de força que acreditamos balizar as 
narrativas: o intento harmonizador na mediação formal e temática dos conflitos em Rosa, e formação de uma consciência das rupturas e desafios da formação identitária angolana no contexto das lutas de libertação - e em alguma medida, da organização social no pós-independência, caracterizada pela violência brutal evidenciada nas relações entre as personagens de Luandino Vieira.

Assim, personagens que, de partida, poderiam ser bastante próximas, mostraram-se bastante distintas, na medida em que observamos suas atitudes e gestos em confluência com aspectos sociológicos, históricos e com os diálogos intelectuais que somavam e concorriam na composição textual e no projeto estético dos escritores.

Acreditamos, por fim, que nesta tarefa inclusa, com possibilidades de ampliação e amadurecimento da leitura, termos percorrido um caminho que se não oferecesse as respostas, pudesse oferecer profícuos questionamentos. 


\section{Bibliografia}

\section{Dos autores:}

Guimarães Rosa:

ROSA, João Guimarães; MEYER-CLASON, Curt. Correspondência com seu tradutor alemão. Rio de Janeiro: Nova Fronteira, 2003.

ROSA, João Guimarães; BIZARRI, Edoardo. Correspondência com seu tradutor italiano. Rio de Janeiro: Nova Fronteira, 2003.

ROSA, João Guimarães. Estas Estórias. Rio de Janeiro: Nova Fronteira, 2001.

Grande Sertão: Veredas. Rio de Janeiro: Nova Fronteira, 2006.

Manuelzão e Miguilim. Rio de Janeiro: Nova Fronteira,

2001.

. No urubuquaquá, no Pinhém. Rio de Janeiro: Nova

Fronteira, 1984.

. Primeiras Estórias. Rio de Janeiro: Nova Fronteira, 2001.

. Sagarana. Rio de Janeiro: Nova Fronteira, 2001.

. Tutaméia. Rio de Janeiro: Nova Fronteira, 1985.

Luandino Vieira

VIEIRA, José Luandino; LABAN, Michel (org.). Luandino: José Luandino Vieira e a sua obra (estudos, testemunhos, entrevistas). Lisboa: Edições 70, 1980.

VIEIRA, José Luandino. A cidade e a infância. São Paulo: Companhia das Letras, 2007.

A vida verdadeira de Domingos Xavier. São Paulo: Ática, 
1980.

De Rios Velhos e Guerrilheiros: O livro dos Rios. Lisboa:

Caminho, 2006.

João Vêncio: seus amores. Lisboa, Edições 70, 1979.

. Lourentino, Dona Antónia de Sousa Neto \& Eu. Lisboa:

Edições 70, 1981.

. Luuanda. São Paulo: Companhia das Letras, 2006.

. Macandumba. Lisboa: Edições 70, 1978.

. No antigamente, na vida. Lisboa: Caminho, 2005.

Nós, os do Makulusu. Lisboa: Caminho, 2004.

. Nosso musseque. Lisboa: Caminho, 2003.

. Velhas Estórias. Luanda: União dos Escritores Angolanos,

1989.

. Vidas Novas. Luanda: União dos Escritores Angolanos,

1985.

Geral:

ABDALA JÚNIOR, B. (Org.) Margens da cultura. São Paulo: Ed. Senac, 2004.

. De voos e ilhas: literatura e comunitarismos. São Paulo:

Ateliê Editorial, 2003.

. Literatura, história e política. São Paulo: Ática, 1989.

. Fronteiras Múltiplas, Identidades Plurais. Um ensaio sobre

mestiçagem e hibridismo cultural. São Paulo: Editora SENAC, 2002. 
ADORNO, W. Theodor. Notas de Literatura I. São Paulo: Duas Cidades: Editora 34, 2003

ALENCASTRO, Luis Felipe. O trato dos viventes: formação do Brasil no Atlântico Sul. São Paulo: Companhia das Letras, 2000.

ALEXANDRE, Valentim. (coord.). Nova história da expansão portuguesa. Volume $X$ : O império Africano (1825-1890). Direção Joel Serrão e A.H. De Oliveira Marques. Lisboa: Editorial Estampa, 1998.

. O Império e a ideia de raça (séculos XIX e XX). In: J. Vala (Coord.). Novos Racismos: Perspectivas Comparativas. Oeiras: Celta, 1999. Velho Brasil, novas Áfricas: Portugal e o Império (18081975). Porto: Afrontamento, 2000.

ANDERSON, Benedict. Comunidades imaginadas: reflexões sobre a origem e a difusão do nacionalismo . São Paulo: Companhia das Letras, 2008.

APPIAH, K. Anthony. Na casa do meu pai. São Paulo: Contraponto, 1997.

ARANTES, Paulo Eduardo. Sentimento de dialética na experiência intelectual brasileira. Dialética e dualidade segundo Antonio Cândido e Roberto Schwarz. São Paulo: Paz e Terra, 1992.

BAKTHIN, Mikhail. Marxismo e filosofia da linguagem. São Paulo: Hucitec, 2002.

BALANDIER, G. As dinâmicas sociais: sentido e poder. São Paulo/Rio de Janeiro: Difel, 1976.

. A noção de situação colonial. In: Cadernos de campo - Revista dos alunos de Pós-graduação em Antropologia da Universidade de São Paulo. São Paulo: USP, n. 3, 1993.

BARTHES, Roland. Aula. São Paulo: Cultrix, 1977. 
BARTHES, Roland. O grau zero da escritura. Trad. Mario Laranjeira. São Paulo: Martins Fontes, 2005.

BENJAMIN, Walter. O narrador. In: Magia e técnica, arte e política: ensaios sobre literatura e história da cultura. 5 ed. São Paulo: Brasiliense, 1993. . Reflexões sobre a criança, o brinquedo e a educação. São Paulo: Duas Cidades; Editora 34, 2002.

BERND, Zilá. Literatura e identidade nacional. Porto Alegre: EDUFRGS, 1992.

BHABHA, Homi K. O local da Cultura. Minas Gerais: Editora UFMG, 2003.

BITTENCOURT, Marcelo. Dos jornais às armas. Trajetórias da contestação angolana. Lisboa: Veja, 1999.

$\mathrm{BLOCH}$, Ernst. O princípio esperança. 3 vols. Rio de Janeiro: Contraponto/Ed. UERJ, 2005/2006.

BOLLE, Willi. Fórmula e fábula: teste de uma gramática narrativa. São Paulo: Perspectiva, 1973.

BOSI, Alfredo. Dialética da colonização. 2 ed. São Paulo: Companhia das Letras, 1992.

. Céu, inferno: ensaios de crítica literária e ideológica. São Paulo: Ática, 1988. . Literatura e resistência. São Paulo: Companhia das Letras, 2002. BRASIL, Assis. Guimarães Rosa. Rio de Janeiro: Organizações Simões, 1969. CANDIDO, A. Literatura e Sociedade. São Paulo: Companhia da Editora Nacional, 1985.

CARVALHAL, Tânia Franco. Literatura comparada: textos fundadores. Rio de Janeiro: Rocco, 1994. 
CHAVES, Rita; MACÊDO, Tania. C; SECCO, Carmen. L. T. Ribeiro. (Org.) . Brasil \& África: Como se o Mar Fosse Mentira. 2. ed. São Paulo; Luanda: Editora da UNESP Editora Chá de Caxinde, 2006.

CHAVES, R. A formação do romance angolano. Entre intenção e gestos. São Paulo: Universidade de São Paulo /Via Atlântica, 1999.

Angola e Moçambique: experiência colonial e territórios literários.

Cotia: Ateliê Editorial, 2005.

COUTINHO, Eduardo F. Guimarães Rosa e o processo de revitalização da linguagem. In: (org.). Guimarães Rosa. Rio de Janeiro: Civilização Brasileira, 1991. (Fortuna Crítica 6).

DAVID, Debora L. Dois cárceres, uma certeza: a morte. (Um estudo comparado de A vida verdadeira de Domingos Xavier de José Luandino Vieira e Memórias do Cárcere de Graciliano Ramos). Dissertação de Mestrado da Pós-Graduação em Estudos Comparados de Literaturas de Língua Portuguesa, USP/FFLCH/DLCV, 2006.

DENIS, Benoit. Literatura e engajamento de Pascal a Sartre. Trad. L. D. A. Roncari. Bauru. São Paulo: EDUSC, 2002.

ERVEDOSA, Carlos. Roteiro da literatura angolana. 4 ed. Luanda: União dos escritores angolanos, s/d.

FANON, Frantz. Em defesa da Revolução Africana. Lisboa, Livraria Sá da Costa Ed., 1980.

. Os condenados da terra. Juiz de Fora: EDUFJF, 2005.

FANTINI, Marli. Guimarães Rosa: fronteiras, margens e passagens. Cotia: Ateliê Editorial; São Paulo: Ed. Senac, 2003. 
FERREIRA, Manuel. Literaturas africanas de expressão portuguesa. Lisboa: Ministério da educação e cultura, Instituto de cultura e língua portuguesa, 1986. (Biblioteca breve)

FINAZZI-AGRÓ, Ettore. A força e o abandono. Violência e Marginalidade na obra de Guimarães Rosa. In: FOOT HARDMAN, Francisco. (org.). Morte e progresso: cultura brasileira como apagamento de rastros. São Paulo: EDUNESP, 1998.

FONSECA, Maria Nazareth S. Imagens de nação em afrodicções literárias. Boletim do Centro de Estudos Portugueses, Belo Horizonte, v. 19, p. 155-168, 1999.

FOOT HARDMAN, Francisco. (org.). Morte e progresso: cultura brasileira como apagamento de rastros. São Paulo: EDUNESP, 1998.

FREITAS, Marcos Cezar (org.). História social da Infância no Brasil. São Paulo: Cortez, 2003.

FREYRE, Gilberto. Um brasileiro em terras portuguesas: introdução a uma possível Iuso-tropicologia acompanhada de conferências e discursos proferidos em Portugal e em terras lusitanas e ex-lusitanas da Ásia, da África e do Atlântico. Rio de Janeiro: José Olympio, 1953.

Nacional, 1971.

- Novo mundo nos trópicos. São Paulo: Companhia Editora . Casa-grande \& Senzala. 44ª ed. Rio de Janeiro: Record, 2001.

GARCIA, José Martins. Linguagem e criação. Lisboa: Assírio \& Alvin, 1973.

GLISSANT, Edouard. Introdução a uma poética da diversidade. Juiz de Fora: EDUFJF, 2005.

GONÇALVES, Perpétua. Para uma aproximação Língua-Literatura em português de Angola e Moçambique. In: Via Atlântica, São Paulo, n. 4, 2000. 
GUIBERNAU, Montserrat. Nacionalismos: o estado nacional e o nacionalismo no século XX. Rio de Janeiro: Jorge Zahar Editor, 1997.

GUILLÉN, Claudio, Entre lo Uno y lo Diverso: Introducción a la Literatura Comparada. Barcelona: Editorial Crítica, 1985.

GUIMARÃES, Vicente. Joãozito - infância de João Guimarães Rosa. Rio de Janeiro: José Olympo, 1972.

HALL, Stuart. Da diáspora: identidades e mediações culturais. Belo Horionte: UFMG; Brasília: Unesco Brasil, 2003.

HAMILTON, Russel G. Literatura Africana: literatura necessária. Lisboa: Edições 70, 1984.

HOBSBAWM, Eric e RANGER, Terence. A invenção das tradições. São Paulo: Paz e Terra, 2008.

HOOKS, bell. Linguagem: ensinar novas paisagens/novas linguagens. In: Revista de Estudos Feministas, Vol. 16, n. 3, 2008.

JAKOBSON, Roman. O que fazem os poetas com as palavras. In: Revista Colóquio/Letras. Ensaio, n. 12, Março/1973, pp. 5-9.

KRISTEVA, Julia. História da linguagem. Lisboa: Edições 70, 1999.

LABAN, Michel. La recherche de l'identité dans No Antigamente, na Vida, de Luandino Vieira. In: Les litteratures africaines de langue portugaise: a la recherche de l'indentité individuelle et nationale. Actes du Colloque International. Paris: Fondation Calouste Gulbenkian, 1985.

LAGES, Susana K. João Guimarães Rosa e a saudade. São Paulo: Ateliê Editorial, 2002.

LEÃO, Ângela Vaz (org.). Contatos e ressonâncias: literaturas africanas de língua 
portuguesa. Belo Horizonte: Editora PUCMinas, 2003.

LEITE, Ana Mafalda. Oralidades e escritas nas literaturas africanas. Lisboa: Colibri, 1998.

LINS, Osman. Lima Barreto e o espaço romanesco. São Paulo: Ática, 1976 (Ensaios, 20).

LISBOA, Henriqueta. O motivo infantil na obra de Guimarães Rosa. In: COUTINHO, Eduardo F. (org.). Guimarães Rosa. Rio de Janeiro: Civilização Brasileira, 1991. (Fortuna Crítica 6).

LOTMAN, I. A estrutura do texto artístico. Trad. M. C. V. Raposo e A. Raposo. Lisboa: Editorial Estampa, 1978.

MACÊDO, Tania. Angola e Brasil: estudos comparados. São Paulo: Via Atlântica, 2001. . Luanda, cidade e literatura. São Paulo: EDUNESP; Luanda: Nzila, 2008.

MARCON, Frank. Diálogos transatlânticos: identidade e nação entre Brasil e Angola. Florianópolis: Letras Contemporâneas, 2005.

MARQUES, A.H. de Oliveira (coord.). Nova história da expansão portuguesa. Volume XI: O Império Africano (1890-1930). Direção Joel Serrão e A.H. De Oliveira Marques. Lisboa: Editorial Estampa, 2001.

MARGARIDO, Alfredo. Estudos sobre literaturas das nações africanas de língua portuguesa. Lisboa: A regra do jogo, 1980.

MARTIN, Vima L. Exclusão social e composição de personagens na ficção de João Antônio e de Luandino Vieira. Via Atlântica (USP), São Paulo, v. 7, p. 183-189, 2004. . Literatura e marginalidade. 1. ed. São Paulo: Alameda, 2008. 
MATA, I. Literatura angolana. Silêncios e falas de uma voz inquieta. Luanda:

Kilombelombe, 2001.

MEMMI, A. Retrato do colonizado precedido pelo retrato do colonizador. Trad. R. Corbisier e M. P. Coelho. Rio de Janeiro: Paz e Terra, 1977.

A estátua de Sal. Rio de Janeiro: Civilização Brasileira, 2008.

MESSIANT, Christine. Luanda (1945-1961): colonisés société coloniale et engagement nationaliste. In CAHEN, Michel (Org). "Vilas" et "Cidades" bourgs et Villes em Afrique lusophone. Paris: I'Harmattan, 1989.

MOURÃO, Fernando Augusto. A sociedade angolana através da literatura. São Paulo: Ática, 1978.

- Continuidade e descontinuidade de um processo de colonização. Tese de livre-docência apresentada à FFLCH. São Paulo: Universidade e são Paulo. $4^{\circ}$ vol.

MÜNSTER, Arno. Ernst Bloch e o novo espírito utópico. In: Filosofia da práxis e utopia concreta. São Paulo: Edunesp, 1993.

NETO, Maria Conceição. O luso, o trópico... os outros (Angola, C. 1900-1975). In: Actas da II Reunião Internacional de História da África, pp. 117-122, 1996.

NUNES, Benedito. O amor na obra de Guimarães Rosa. In: ROSA, João Guimarães. Ficção completa. Rio de Janeiro: Nova Aguilar, 1994.

PACHECO, Ana Paula. Lugar do mito: narrativa e processo social nas Primeiras Estórias de Guimarães Rosa. São Paulo: Nankin, 2006.

PADILHA, Laura C. Entre voz e letra: o lugar da ancestralidade na ficção angolana do século XX. Niterói: EDUFF, 2007. . Novos pactos, outras ficções. Ensaios sobre literaturas afro- 
Iuso-brasileiras. Porto Alegre: EIDUPUCRS, 2002.

PIZARRO, Ana. (org.). América Latina: palavra, literatura e cultura. São Paulo: UNICAMP, 1994. vol. 2: Emancipação do Discurso.

PRATT, Mary Louise. Os olhos do império. Relatos de viagens e transculturação. Florianópolis: EDUSC, 1999.

RAMA, Ángel. Transculturación Narrativa en América Latina. Méjico D.F.: Siglo XXI Editores, 1987. . Literatura, Cultura e Sociedade na América Latina. Belo Horizonte: Editora UFMG, 2008.

RESENDE, Vânia Maria. O menino na literatura brasileira. São Paulo: Perspectiva, 1988.

RIBAS, Oscar. Dicionário de regionalismos angolanos. Matosinhos: Contemporânea, 1997.

RODRIGUES, Urbano Tavares. Luandino Vieira: uma língua de autor. In: Les litteratures africaines de langue portugaise: a la recherche de l'indentite individuelle et nationale. Actes du Colloque International. Paris: Fondation Calouste Gulbenkian, 1985.

RONCARI, Luiz. O Brasil de Rosa: o amor e o poder. São Paulo: EDUNESP, 2004. . O cão do sertão: literatura e engajamento. Ensaios sobre João

Guimarães Rosa, Machado de Assis e Carlos Drummond de Andrade. São Paulo: EDUNESP, 2007.

ROSENFELD, Anatol. Literatura e Personagem. In: CÂNDIDO, Antonio. (org). A personagem de ficção. São Paulo: Perspectiva, 2004. 
ROSENFIELD, Kathrin. Desenveredando Rosa. A obra de J.G. Rosa e outros ensaios rosianos. Rio de Janeiro: Topbooks, 2006.

RUI, Manuel. Entre mim e o nômade - a flor. ABREU, Antero et alii. Teses angolanas (Documentos da VI Conferência dos escritores afro-asiáticos). Lisboa: Edições 70; Luanda: União dos escritores angolanos, 1981.

SAID, Edward. Cultura e imperialismo. São Paulo: Companhia das letras, 2000.

SANTIAGO, Silviano. Uma literatura nos trópicos: ensaios sobre dependência cultural. Rio de Janeiro: Rocco, 2000.

SANTILLI, M. A. Paralelas e tangentes. São Paulo: Via Atlântica, 2003.

SANTILLI, M. A. Estórias africanas. História e antologia. São Paulo: Ática, 1985 (Fundamentos).

SECCO, Carmen L. T. Ribeiro. A magia das letras africanas: um ensaio sobre as literaturas de Angola e Moçambique e outros diálogos. Rio de Janeiro: Quartet, 2008.

SERRANO, Carlos Moreira Henriques. Angola: nasce uma nação. Um estudo sobre a construção da identidade nacional. Tese de doutoramento em Antropologia Social. São Paulo: FFLCH, da Universidade de São Paulo, 1988. (Texto policopiado).

SPERBER, Suzi Frankl. Caos e cosmos: leituras de Guimarães Rosa. São Paulo: Duas Cidades, 1976.

STARLING, Heloisa M. M. Lembranças do Brasil: Teoria, política, história e ficção em Grande Sertão: veredas. Rio de Janeiro: Revan, UCAM, IUPERJ, 1999.

VANSINA, Joseph. A tradição oral e sua metodologia. In: KI-ZERBO, J. Trad. B. Turquetti et al.; revisão técnica F. A. A.. Mourão et al. São Paulo História geral da África. Paris; São Paulo: Unesco; Ática, 1982. 